\title{
Stimulation of Bioprocesses by Ultrasound
}

Barbara Kwiatkowska, Jason Bennett, Joe Akunna, Graeme M. Walker and David H Bremner*

School of Contemporary Sciences, University of Abertay Dundee, Bell Street, Dundee, DD1 1HG, UK

\section{Abstract}

Ultrasound (US) has become a ubiquitous technological process in a large variety of scientific disciplines. However, little information exists on the use of ultrasound to enhance biological processes and/or processing and consequently this paper provides an overview of work reported to date on this topic. This review provides a brief introduction to ultrasound and the history of ultrasound as applied to bioprocesses. This is followed by a discussion of the influence of US on discrete enzyme systems, enzymes used in bioremediation, microbial fermentations and enzymatic hydrolysis of biopolymers. Augmentation of anaerobic digestion by US is then considered along with enhancement of enzymes in food science and technology. The use of ultrasonically stimulated enzymes in synthesis is then considered and other relevant miscellaneous topics are described. It is concluded that the precise mechanism of action of US in bio-processing remains to be elucidated though a variety of plausible suggestions are made.

\section{Terms Used}

$\begin{array}{ll}\text { AD } & \begin{array}{l}\text { anaerobic digestion } \\ \text { AS }\end{array} \\ \text { audible sound } \\ \text { the percentage of the time that US is inputted } \\ \text { Ionic Liquids } & \text { ILs } \\ \text { Low frequency } & 20 \mathrm{kHz}-100 \mathrm{kHz} \\ \text { High frequency } & 100 \mathrm{kHz}-2 \mathrm{MHz} \\ \text { Hz } & \text { Hertz } \\ \text { Power } & \text { amplitude, energy, intensity, } \\ \text { SSF } & \text { simultaneous saccharification and fermentation } \\ \text { US } & \text { ultrasound } \\ \text { VSS } & \text { volatile suspended solids }\end{array}$

\section{Introduction}

Sound frequency above $18 \mathrm{kHz}$ is considered to be ultrasound (US) and a huge amount of research has gone into the application of ultrasound at both high and low power. The use of the latter is mainly confined to medical ultrasonography while the former has a 
myriad of uses including ultrasonic welding, degassing of solutions, defect detection and sonochemistry. When US is applied to an aqueous solution or suspension an increase in mixing, shearing and mass transfer is observed. Under certain conditions cavitation is produced which manifests itself in the production of tiny bubbles which implode to produce so called "hotspots" which tend to generate highly reactive hydroxyl radicals and unusual chemical transformations (Bremner, 1990).

Generally, the ultrasonic equipment alluded to in this review is one of three types: an ultrasonic probe system (usually $20 \mathrm{kHz}$; Fig 1 ), an ultrasonic bath (around $40 \mathrm{kHz}$; Fig. 2), or an ultrasonic transducer fitted to a glass reactor (from $300-1100$ kHz; Fig. 3).

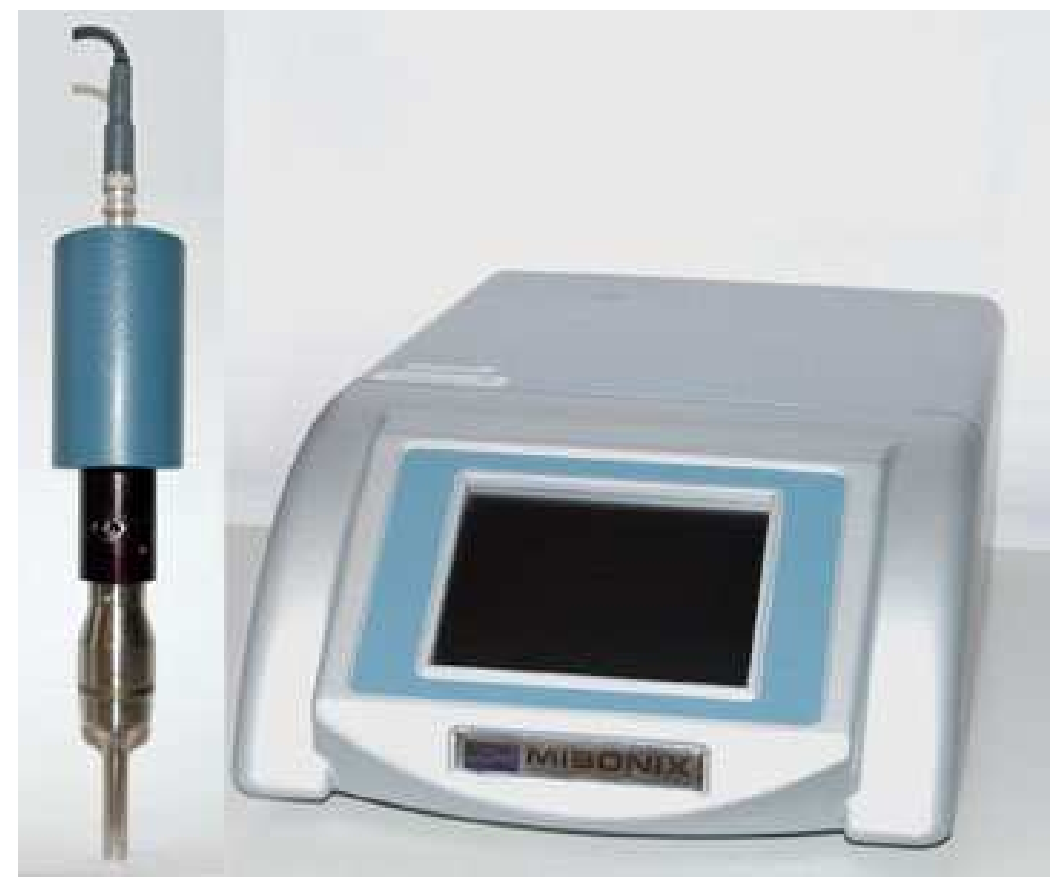

Figure 1: $20 \mathrm{kHz}$ probe with amplifier and signal generator unit

water + detergent

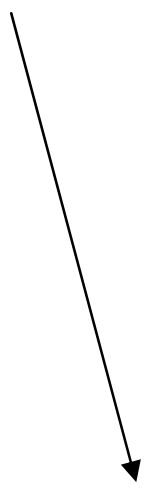

reaction mixture

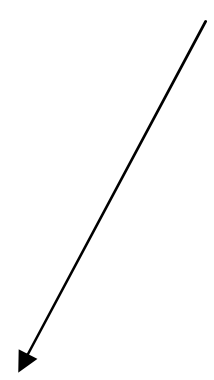




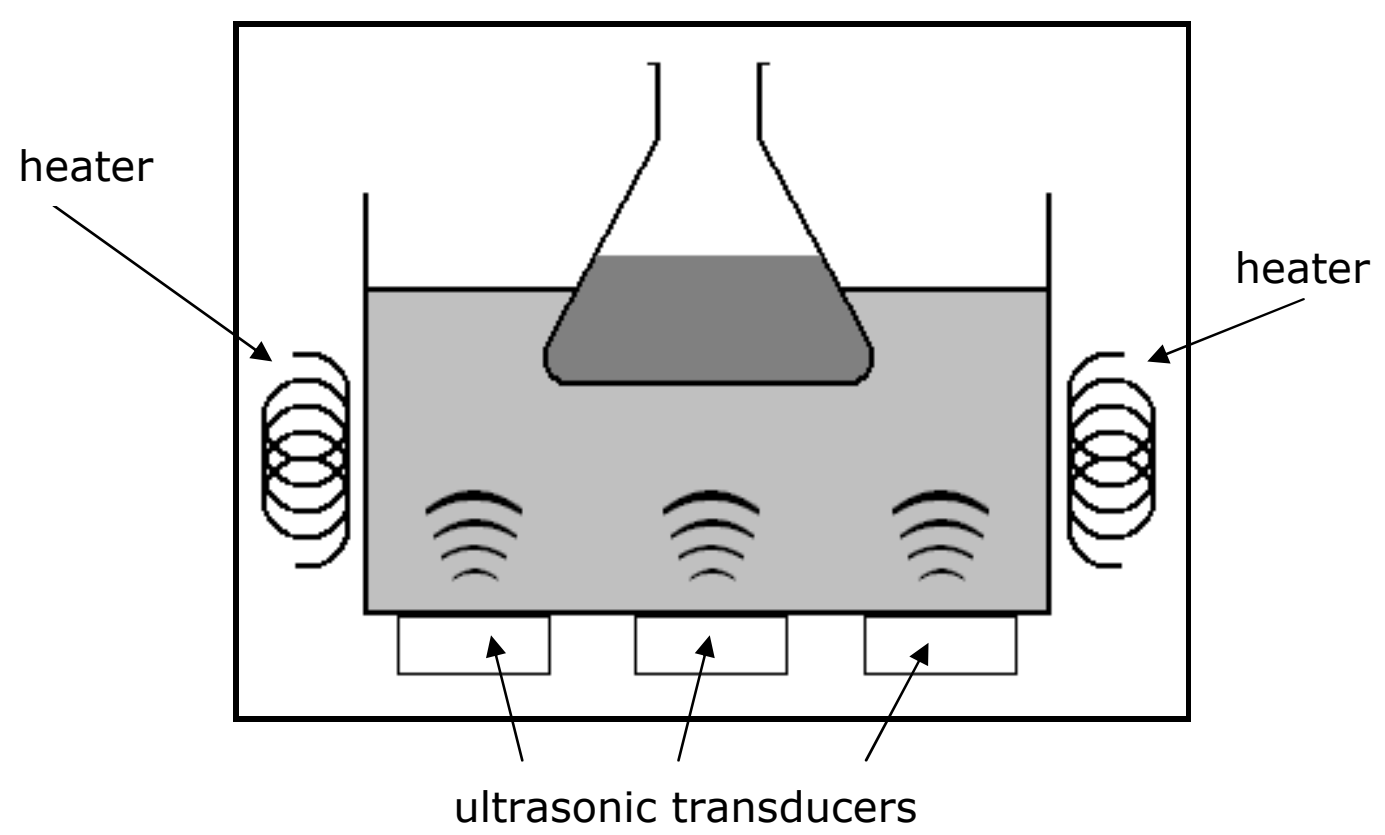

Figure 2: Schematic diagram of an ultrasonic bath

amplifier and signal generator

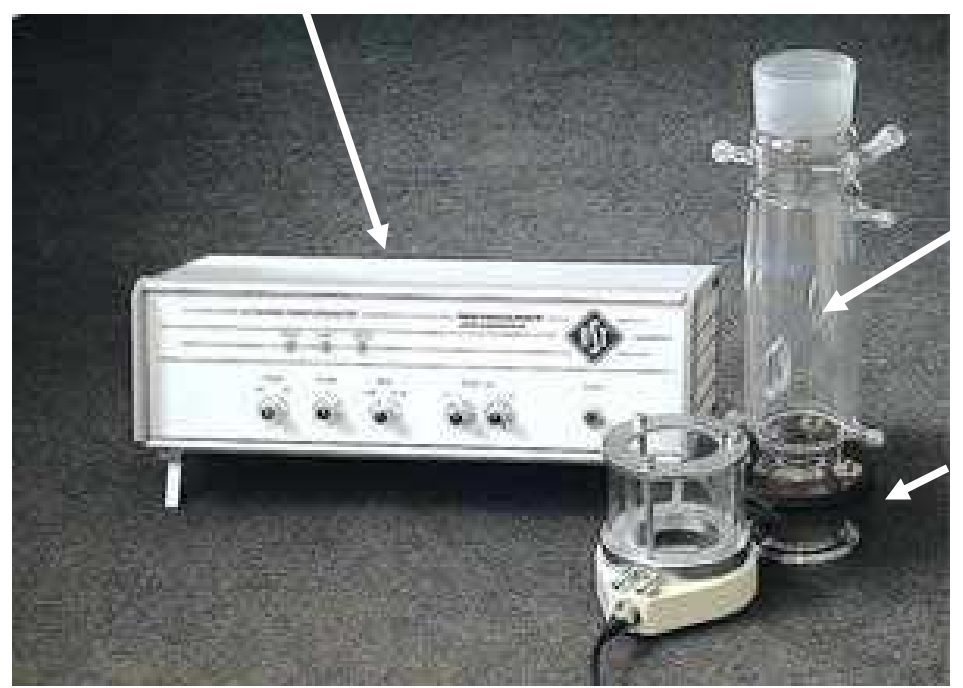

jacketed

glass

reactor

transducer

Figure 3: Ultrasonic transducer and glass reactor

(Meinhardt Ultraschalltechnik, Leipzig)

It is useful here to briefly discuss the difference between low and high frequency. Much of the work described has been performed using equipment operating at $20 \mathrm{kHz}$ (probe system) or $40 \mathrm{kHz}$ (ultrasonic bath) due to the fact that these have been the frequencies which have traditionally been generally available and are classed herein as Low Frequency. In the last 20 years ultrasonic transducers have become available which operate at frequencies from about $350 \mathrm{kHz}$ upwards and they are classed here 
a High Frequency." Thus, low frequency is defined as being below $100 \mathrm{kHz}$ and high frequency is greater than this value

Over the years there have been many excellent reviews of the uses of ultrasound in biology, engineering, geology, chemistry, physics and medicine but few reviews have considered the application of US to biotechnology and bioprocess technology. In an early review in 1992, Sinisterra gave an overview of the application of ultrasound to biotechnology and included considerable discussion of the way in which US influenced biotechnological processes. However, little information was available at that time and the review included several unpublished examples from the author's own work (Sinesterra, 1992). The use of ultrasound for "intensifying the performance of live biocatalysts" has been reviewed and focussed mainly on live biological systems and on the design requirements for sonobioreactors (Chisti, 2003). Although not totally relevant to the current review, the use of enzymes in organic media has reported that both ultrasound and microwave technology can be employed to increase reaction rates in organic solvents with minimal water present (Gupta and Roy, 2004). Recently, "the state of the art" of the use of ultrasound in biotechnology has also been reviewed (Rokhina et al., 2009). The authors discussed a wide variety of bio-processes including cell disruption, biofuel production, process monitoring, biocatalysis, biosensors and activated sludge treatment.

Only the use of ultrasound to enhance important bioprocesses such as enzymatic transformations, environmental remediation, fermentations, anaerobic digestion, food processing and enzyme assisted chemical synthesis will be considered here. The huge body of work involving ultrasound in the disruption of cells, the extraction of compounds from plant material or chemical syntheses of biomolecules is not covered in this review.

\section{History of Ultrasound and Bioprocesses}

The "Father of Ultrasonics", Paul Langevin, was the first to transmit sound waves in water ostensibly as a method of detecting icebergs to avoid another Titanic disaster (Bremner, 1990).

However, it was reported that Langevin merely managed to kill a number of fish and thus began the interaction of US with biomolecules. Later, the physical and biological effects of intense high frequency sound were described and it was reported that red blood corpuscles were rapidly destroyed and small fish and frogs were killed but mice survived for 20 minutes (Wood and Loomis, 1927). Interestingly, while investigating the bactericidal action of audible sound, (Flosdorf and Chambers, 1933) found that egg albumin was almost instantly coagulated at $30^{\circ} \mathrm{C}$. They extended their work to report on the decreased antigenic activity and altered 
specificity of egg albumin coagulum produced by sonic radiation (Flosdorf and Chambers, 1935).

\section{Effects of Ultrasound on Enzymes}

Ultrasound has the potential to greatly influence the activities of enzymatic processes provided the energy inputted is not too great to disrupt the function of the enzyme under study. The application of low-power ultrasound increases growth in microbial cell cultures but high power causes cell disruption and hence can be considered as microbicidal. US has also been used to extract and release intracellular enzymes and their subsequent activity can be further enhanced by the application of US. However, it must be stressed that the influence of sonic radiation on the activity and stability of enzymes depends on the sonication parameters and the specific enzyme preparation.

Several authors have reported that high intensities of ultrasound cause a decrease in activity of many enzymes (Ali Kashkooli et al., 1980) although interestingly it was reported that "inactivation of enzymes in solution by $3-\mathrm{MHz}$ ultrasound in the power range 1-3 W/L, which has been reported by other investigators, is, in fact, due to the presence of rubber materials used as part of the containing vessel during the experiments" (Macleod and Dunn, 1966). These same authors later reported (Dunn and Macleod, 1968) an extensive study of the effects of noncavitating ultrasound on solutions of alpha-chymotrypsin, trypsin, aldolase, lactate dehydrogenase and ribonuclease. Irradiations were carried out at different $\mathrm{pH}$ values and temperatures using 1 $\mathrm{MHz}$ ultrasound at a power of $75 \mathrm{~W} / \mathrm{mL}, 10$ min continuous exposure and $11 \mathrm{MHz}$ ultrasound at a power of $1000 \mathrm{~W} / \mathrm{mL}, 0.1 \mathrm{~s}$ pulses for 200s. In addition, the enzymes were irradiated with US having an intensity range of $0.5-35 \mathrm{~W} / \mathrm{mL}$ at frequencies of 1,9 and $27 \mathrm{MHz}$ with temperature and $\mathrm{pH}$ constant. These results indicated that cavitation is a necessary requirement for ultrasonic denaturation of the five enzymes investigated (Dunn and Macleod, 1968).

One of the earliest evaluations of the effect of sonication on lipase activity showed that porcine pancreatic lipase was inactivated by US at $50^{\circ} \mathrm{C}$ but was stable at $30^{\circ} \mathrm{C}$ or below. It was found that sonication of lipase and olive oil for less than 5 minutes produced 2.7 times as much free fatty acid compared to the absence of ultrasound. Furthermore the hydrolysis of tripalmitin was achieved by use of US and lipase (Goodman and Dugan Jr., 1970). Catalase and malate dehydrogenase (MDH) have been subjected to $20 \mathrm{kHz}$ ultrasound at $27^{\circ} \mathrm{C}$ and while the former was not inactivated by US, inactivation of the latter increased exponentially with the duration of sonication and depended upon the initial enzyme concentration. It 
was suggested that the inactivation was not the result of cavitation or thermal heating but rather due to acoustic microstreaming (Ali Kashkooli et al., 1980). The activity of some immobilised enzymes can also be increased with US. For example, a-chromotrypsin immobilised on agarose gel was used in a proteolytic reaction with casein as substrate along with $20 \mathrm{kHz}$ ultrasound. The sonication increased the activity over 2 times that of normal conditions at $\mathrm{pH} 8$ and $35^{\circ} \mathrm{C}$ although there was some evidence for inactivation after four repeated uses. Surprisingly, when acetyltyrosine ethyl ester was used as substrate, no acceleration of activity was seen with US. The effectiveness of sonication was ascribed to promotion of the penetration of casein into the gel (Ishimori et al., 1981).

An early example of the positive effect of US is the continuous production of the intra-cellular enzyme glucose oxidase (GOD) from Aspergillus spp. with "mild" ultrasound. GOD translocation out of the cell was facilitated (optimum at pH 7.5 and at $30^{\circ} \mathrm{C}$ ) by $20 \mathrm{kHz}$ ultrasound (15W). Microscopic observation and ATP measurements indicated that the mycelia were not damaged during the $5 \mathrm{~h}$ of US treatment (Ishimori, et al. 1982).

Ultrasound also affects the release and activity of invertase from A. niger (Vargas, et al. 2004). Invertase, an enzyme used for sucrose hydrolysis, converts the substrate sugar into fructose and glucose $(1: 1)$ which is much sweeter and is used in production of chocolate and other sweet food products. A. niger was cultivated in a medium containing either sucrose and peptone or sugar-cane molasses and peptone and sonicated for 2-10 min with low or medium power levels at $20 \mathrm{kHz}$ frequency at $28-33^{\circ} \mathrm{C}$. Both amplitudes showed considerable increase in total invertase activity due to cell disruption, initially releasing the invertase, and then after 4 min ultrasound, activation of the enzyme was observed. The best conditions overall were observed in molasses medium containing peptone and sonication with low power for $8 \mathrm{~min}$.

Sakakibara, et al. (1996) have reported that sucrose hydrolysis by invertase is also accelerated by ultrasound irradiation. Alteration of $\mathrm{pH}$, sucrose concentration and sound intensity indicated that at low sucrose concentration the activity of the invertase was increased by around $130 \%$ at $\mathrm{pH} 4$ and $25^{\circ} \mathrm{C}$. However, with high sucrose concentrations the activity of the invertase decreased on sonication using $815 \mathrm{kHz}$ US. The effect of US (between 1 and $11 \mathrm{MHz}$ ) on the activity of glucoamylase bound to a porous polystyrene matrix was investigated by Schmidt et al., (1987b) and the activity was found to have increased as determined by measuring the type and concentration of the substrate, carrier particle size, flow rate and ultrasonic frequency. Further work by the same researchers on alpha-amylase and glucoamylase bound to polystyrene showed that the maximum increase in activity (200\%) 
was at 7.6 MHz (Schmidt et al., 1987a). A mathematical model was proposed which indicated that the mechanism for the ultrasonic effect could be explained in terms of a decrease in the unstirred diffusion layer around the polymer particles.

The effect of ultrasound $(20 \mathrm{kHz})$ on the hydrolysis of corn, rice and wheat starch using alpha-amylase enzymes produced by Bacillus species and Bacillus licheniformis has been studied at $40{ }^{\circ} \mathrm{C}$ and at pH 6.5 (Apar et al., 2006). In some cases sonication was found to be beneficial but for starch hydrolysis with alpha-amylase at 40 and $50^{\circ} \mathrm{C}$ the control samples showed higher starch hydrolysis and lower residual enzyme activity.

Some industrially important glycosidase enzymes are also stimulated by ultrasound (Barton et al., 1996). The activities of alpha-amylase and amyloglucosidase toward starch and glycogen hydrolysis and of invertase toward sucrose hydrolysis were investigated using a $60 \mathrm{~W}$ ultrasonic bath (with no further details given). Increases in rates were noted with US at most concentrations with a particular enhancement in invertase activity towards sucrose hydrolysis and a decrease in enzyme inhibition at high substrate concentrations. The authors proposed that possible reasons for this stimulation of activity were enhanced mixing and disruption of intra- and inter-molecular substrate:molecule interactions at high concentrations. Interestingly, in the invertasecatalysed hydrolysis of sucrose without US, the optimum substrate concentration was $0.7 \mathrm{M}$ at $40^{\circ} \mathrm{C}$ but with US this was increased to 1.0M. An unexplained but consistent increase in rate at the highest sucrose concentration studied was also observed (Figure 4).

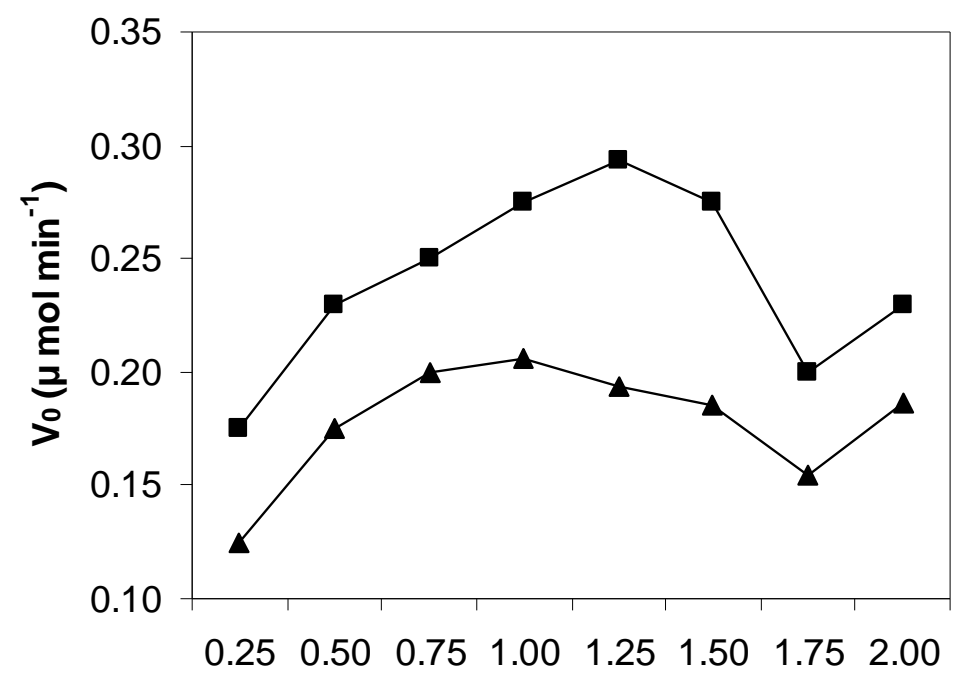

[Sucrose] M

Figure 4: Invertase-catalysed hydrolysis of sucrose in the presence $(\boldsymbol{\square})$ and absence ( $\boldsymbol{\Delta})$ of ultrasound. (Adapted from Barton et al., 1996). 
Considerable research effort has been applied to the potential use of ultrasound in the area of commercial enzymes. For example, buffered solutions of six enzymes, alcohol dehydrogenase (ADH), malate dehydogenase (MDH), glucose 6-phosphate dehydrogenase (G6PDH), lactate dehydrogenase (LDH), alkaline phosphatase (AP) and beta-glucosidase $(\beta G)$ were sonicated with a sonic probe system operating at $20 \mathrm{kHz}$ over a range of powers up to $40 \mathrm{~W}$ at $<$ $5{ }^{\circ} \mathrm{C}$ (Özbek and Ülgen, 2000). The enzymes had variable stabilities under the conditions chosen with AP being completely stable but G6PDH being 70\% inactivated (Table 1). As expected, loss of enzyme activity increased with higher ultrasonic intensity (Özbek and Ülgen, 2000) and the authors suggested that the inactivation mechanisms varied and were specific to the enzyme and that sonication processing time was also important. Özbek and Ülgen (2000) proposed that increasing the viscosity of the solutions with glycerol was detrimental to ADH (the only enzyme studied) since the physical properties of the fluid and the shear forces generated are important factors in enzyme inactivation.

Table 1: Relative stabilities of enzymes after ultrasonic treatment (Adapted from Özbek and Ülgen, 2000).

\begin{tabular}{|l|l|l|}
\hline Enzyme & $\begin{array}{l}\% \text { Stability 32 W and } \\
10 \% \text { duty cycle }\end{array}$ & $\begin{array}{l}\% \text { Stability 40 W and } \\
90 \% \text { duty cycle }\end{array}$ \\
\hline AP & 100 & 100 \\
\hline$\beta$ G & 85 & 55 \\
\hline LDH & 81 & 54 \\
\hline MDH & 66 & 33 \\
\hline ADH & 64 & 44 \\
\hline G6PDH & 52 & 29 \\
\hline
\end{tabular}

The use of enzymes in the textile industry has become increasingly popular as they can replace harsh chemical conditions but generally the enzymes used are not active enough to produce comparable results. Cellulase and pectinase enzymes, particularly, have been investigated and ultrasound has been shown to improve their performance in the processing of cotton textiles. Surprisingly, sonication of pectinase solutions does not impair the enzyme structure but does improve their performance. Alkaline pectinase seems to be superior to acidic pectinase for the bio-preparation of greige cotton (Yachmenev et al., 2001). Later work showed that the maximum benefit was obtained when the concentration of the enzyme was low and although the enzymatic activity was enhanced there was no decrease in textile strength. The combined use of enzyme/sonication treatment of cellulosic textiles offers considerable saving in that there is lower consumption of expensive 
enzyme, shorter processing time, less fibre damage and the treated textile is much more uniform (Yachmenev et al., 2002; Yachmenev et al., 2004). These authors have reviewed their work on the effect of ultrasound on industrial enzymes used in bio-preparation/bioprocessing and concluded that the maximum benefit of the enzyme processing solution was obtained at a lower concentration than recommended by the manufacturer. The Advanced Sonic Processing Systems Corporation equipment used in the above study is worthy of note (Figure 5) in that it is a dual system ( $16 \mathrm{kHz}$ and $20 \mathrm{kHz}$ ) which produces a "beat" frequency that develops a highly energized zone which continually oscillates and ensures consistent processing in the reaction chamber (Yachmenev et al. 2006)

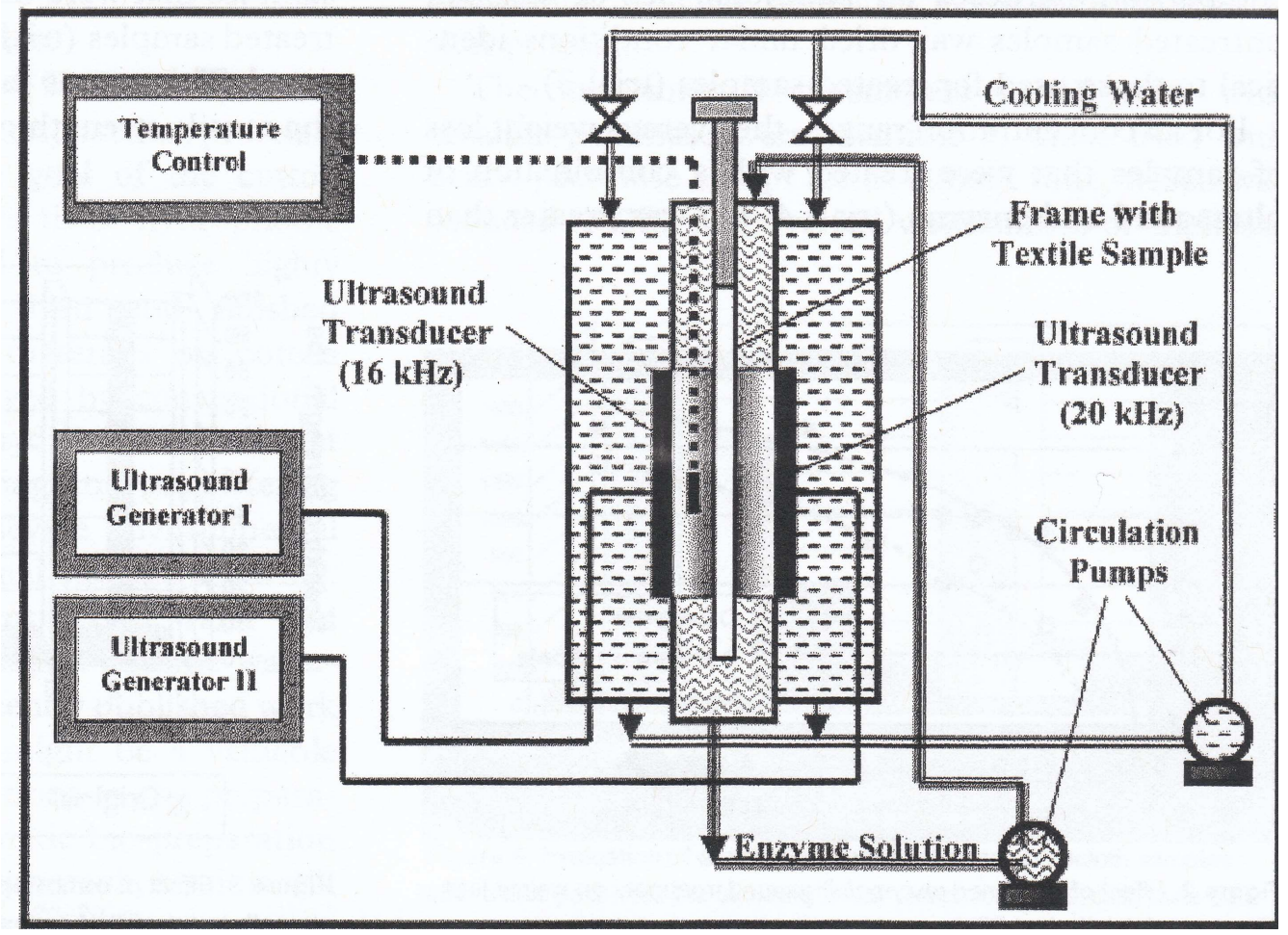

Figure 5: Diagram of the cell for combined enzyme/ultrasonic treatment of textiles (from Yachmenev et al., 2002)

Encapsulating proteins in polymeric microspheres is useful for drug delivery but the proteins may be damaged by ultrasound during encapsulation. The effects of ultrasonic power at a frequency of $27 \mathrm{kHz}$ on the function and structure of trypsin were investigated. Results showed that trypsin activity decreased with increasing ultrasonic power and duration probably due, the authors surmise, to conformational or molecular changes. However, the additives, Tween 80 and mannitol, could protect trypsin from inactivation caused by the ultrasound (Tian et al., 2005).

Comparative studies of lipase-catalyzed hydrolysis of soy oil in a solvent-free system have been carried out by Liu et al., (2008) who found that ultrasonic power of $1.64 \mathrm{~W} / \mathrm{mL}$ produced 
satisfactory lipolysis. The influence of temperature, $\mathrm{pH}$, enzyme concentration and water/oil ratio was investigated and it was found that ultrasound led to increased reaction rates with relatively high enzyme loading and the need for less water. The overall rate of enzymatic hydrolysis was over twice that without ultrasonic treatment (Liu et al., 2008).

Collagen is one of the most useful biomaterials for applications such as drug delivery systems, wound dressings and tissue scaffolds. Generally, tissues rich in collagen such as skin and tendon are extracted with proteases such as pepsin but conventional processing is time consuming and leads to large amounts of collagen residues. The enzymatic extraction of bovine tendon collagen by US $\left(40 \mathrm{kHz}, 120 \mathrm{~W}, \sim 20^{\circ} \mathrm{C}\right)$ showed an increased yield of $120 \%$ and shorter extraction times compared to the conventional pepsin method ( $\mathrm{Li}$ et al. 2009). The authors suggest that enhancement was most likely due to increased enzyme activity and dissolution of the collagen fibrils because the US dispersed the pepsin aggregates and opened up the collagen fibrils to facilitate hydrolysis. Spectroscopic measurements showed that the triple helix structure of collagen remained intact. Figure 6 shows a schematic representation of the US-pepsin extraction ( $\mathrm{Li}$ et al., 2009).

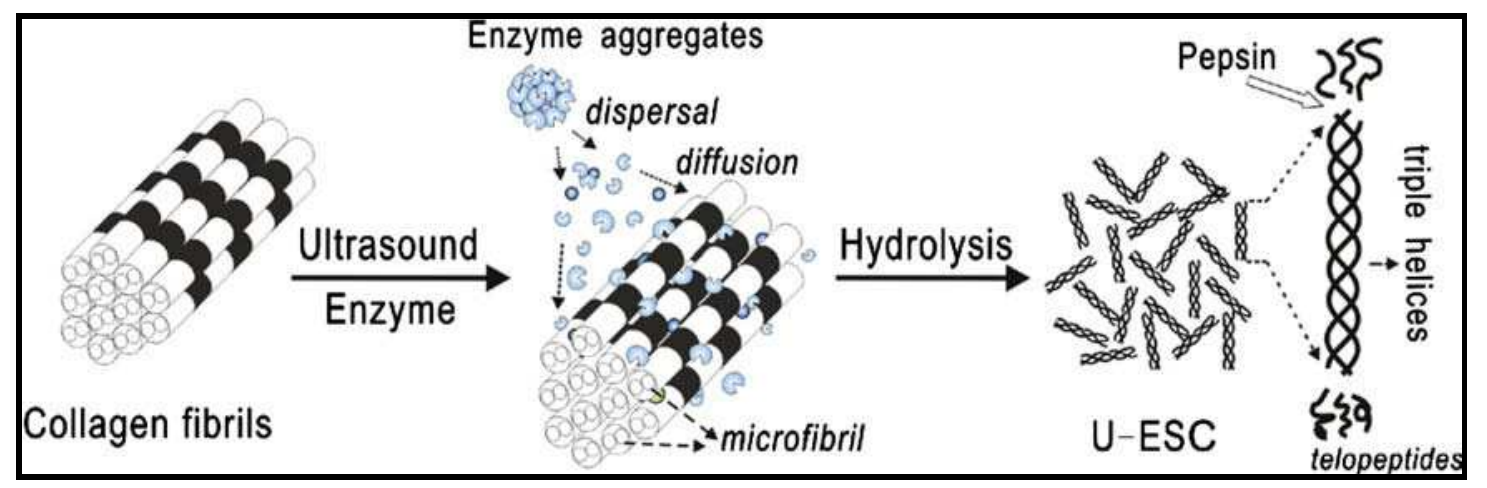

Figure 6: US-pepsin extraction of bovine tendon collagen where UESC represents Ultrasound-Enzyme Soluble Collagen (from Li et al., 2009).

\section{Enzymes in Environmental Remediation}

The use of ultrasound in environmental remediation can be considered as a green technological application particulary when allied to bioprocesses. Basto et al. (2007) found that when laccase from Trametes villosa and bovine serum albumin was sonicated, this led to deactivation of the enzyme due to the formation of high molecular weight aggregates. The inactivation was mainly caused by generation of hydroxyl radicals caused by cavitational implosion affecting the cystine residues, although some protection was 
afforded by the addition of polyvinyl alcohol to the laccase by reducing the detrimental ultrasonic effects. This observation prompted an investigation into the use of laccase for the decolourization of dye solutions and it was found that $65 \%$ of the colour could be removed by treating with ultrasound $(20 \mathrm{kHz}, 150$ $\mathrm{kHz}$ and $500 \mathrm{kHz}$ at $50 \pm 2{ }^{\circ} \mathrm{C}$ ) together with enzyme stabilisation using polyvinyl alcohol. This level of efficiency contrasted very well with that obtained for the enzyme alone, where only $20 \%$ decolourization was observed after $1 \mathrm{~h}$ of treatment with optimum results being obtained with ultrasound frequencies of $150 \mathrm{kHz}$.

Another use for enzymes with ultrasound $(423 \mathrm{kHz} ; 5.5 \mathrm{~W} ; 28$ $\pm 1^{\circ} \mathrm{C}$ ) in environmental remediation has been described by Entezari and Petrier (2003). They investigated the degradation of phenol and substituted phenols (pollutants found in waste streams from a variety of industries) using sonolysis, horseradish peroxidase and a combination of both in aqueous media. They found that the efficacy of the process depended on the structure of the phenols employed with phenol and halogenated phenols most successfully treated with a combination of US and enzyme with polyethylene glycol addition being necessary to protect the enzyme. In an extended study using only phenol as the substrate it was found that horseradish peroxidase, hydrogen peroxide and US at a frequency of $423 \mathrm{kHz}$ accelerated the degradation of phenol. Addition of polyethylene glycol (PEG) to the solution enhanced the degradation rate further and the authors noted that "ultrasonic waves not only preserved the activity of the peroxidise in the period of the sonication, but it also probably had a positive effect on the lifetime of the enzyme" (Entezari and Petrier, 2004).

The use of enzymes in conjunction with sonication is considered to be an eco-friendly technology for the treatment of wastewater from heavy polluting industries such as leather and tanning. For example, Jian et al. (2008) showed that although ultrasound $\left(40 \mathrm{kHz} ; 40{ }^{\circ} \mathrm{C}\right)$ had little effect on alkaline protease activity from Bacillus licheniformis this treatment could accelerate enzymatic hydrolysis of untanned solid leather waste by around $25 \%$. Sonication promotes the passage of the protease through the pores of the leather skin and encourages the breakdown of helical regions of collagen. Overall, the process can be performed at low temperature without the need for harmful chemicals and the resulting solution can be processed into powder form for other uses as a raw material.

Allinase is a glycoprotein found in Allium plants and is well known to have a variety of positive biological effects. Purified allinase with a molecular weight of $54,000 \mathrm{Da}$ was subjected to 40 $\mathrm{kHz}$ US with an intensity of $0.5 \mathrm{~W} / \mathrm{mL}$. This low frequency, mild intensity ultrasound increased allinase activity in a pure sample by around $50 \%$ but in the presence of exogenous pyridoxal 5'- 
phosphate (PLP) and potassium ions, activity was decreased though $\mathrm{Fe}^{2+}$ ions had a positive effect. Surprisingly, the addition of PLP and both potassium and iron ions showed opposite effects in the absence of ultrasound. These observations were attributed to US retarding the inhibitory effect of L-cysteine (Wang et al., 2010a).

There is increasing consumption of seaweeds, particularly in the Western world. However, there is little data dealing with the presence of inorganic contaminants which can be accumulated by these aquatic plants and current information has been obtained using a wet decomposition procedure using acids and hydrogen peroxide together with microwave treatment. However, a novel ultrasonically enhanced enzymatic hydrolysis process has been developed for pre-treating edible seaweed (Pena-Farfal et al., 2005). Three enzymes, alpha-amylase, pepsin and trypsin were evaluated along with different $\mathrm{pH}$, sonication temperature, ultrasound frequency, ionic strength, hydrolysis time, extraction volume and enzyme mass using a Plackett-Burman experimental design. Results indicated that there was no significant difference between the sonicated and silent extractions probably due to the elevated salt content producing a high ionic strength solution. Nevertheless, there was some advantage in using ultrasound, since assisted enzymatic hydrolysis could be completed in 30 min with 35 $\mathrm{kHz}$ US at $37^{\circ} \mathrm{C}$ compared to $6 \mathrm{~h}$ for the conventional enzymatic process.

Yang et al. (2010) have recently shown that when a culture of Brevibacterium was treated with $20 \mathrm{kHz}$ ultrasound for 1 min every $4 \mathrm{~h}$ the amount of cholesterol oxidase produced was increased by $18 \%$. Transmission electron microscopy of the bacterial cell walls showed that, initially, holes appeared in the cytoplasmic region but increased irradiation caused rupture and loss of integrity of the cells.

\section{Effects of US on Microbial Fermentations}

Fermentation processes also can benefit from sonication. Immobilisation of yeast cells such as Saccharomyces cerevisiae increases their tolerance to stress by creating protective microenvironments and the application of ultrasound is one technique which can be used to move and manipulate yeast cells prior to immobilisation. Radel et al. (2000) have investigated yeast cell viabilities using US at frequencies slightly above $2 \mathrm{MHz}$ and at 30 ${ }^{\circ} \mathrm{C}$. Although some changes in morphology and agglomeration of yeast cells were observed, there appeared to be no loss of yeast viability even when the cells were in a suspension of $12 \%(\mathrm{v} / \mathrm{v})$ ethanol. Further work on the influence of ultrasound and $\mathrm{Ca}^{2+}$ concentration on the proliferation of $\mathrm{S}$. cerevisiae has been reported 
by Bochu et al. (2003) who found that low intensity ultrasound ( 24 $\left.\mathrm{kHz}, 2 \mathrm{~W}, 29^{\circ} \mathrm{C}\right)$ greatly enhanced the total $\mathrm{Ca}^{2+}$ content within the cells which in turn increased the yeast biomass produced. They suggested that ultrasound promoted cell membrane permeability and altered surface potential resulting in activation of the calcium channels. Ultrasonic stimulation of yeast cells produced three times as much intracellular $\mathrm{Ca}^{2+}$ and efficiently shortened the logarithmic growth phase compared to the non-sonicated cultures. In a related study of the physiological characteristics of S. cerevisiae, the same authors found that ultrasonic stimulation enhanced the fermentation and proteinase activity of the parent cells but had no effect on the fermentation and ascospore ratio of the descendants though they did exhibit reduced flocculation (Lanchun et al., 2003).

Low frequency, low energy ultrasound has been shown to stimulate production of riboflavin by Ecemothecium ashbyii by decreasing the fermentation time and increasing the production of riboflavin 5 fold compared to controls (Chuanyun et al., 2003). Further work (Chuanyun et al., 2004) indicated that the optimal stimulation time was around $110 \mathrm{~h}$ with the US $\left(24 \mathrm{kHz}, 28-30{ }^{\circ} \mathrm{C}\right)$ being applied every $1.5 \mathrm{~h}$. Fermentation with $A$. terreus is commercially used to produce the cholesterol-lowering drug lovastatin. The positive effects of low $\left(957 \mathrm{~W} \mathrm{~m}^{-3}\right)$ medium (2870

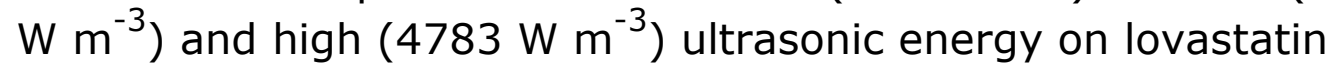
production in a slurry bubble column sonobioreactor were examined by Herran et al.(2008). Sonication at any power of ultrasound did not affect biomass growth profiles but medium and high intensity reduced lovastatin production and altered growth morphology, disrupted the fungal pellets and caused the biomass to grow mainly as dispersed hyphae. The overall conclusion was that ultrasound could be used to alter morphology and broth rheology without affecting growth of filamentous fungi. Sonication appeared to influence primary and secondary growth metabolism differently depending on the conditions.

One of the main obstacles in the improvement of gentamicin (GM) productivity is considered to be the structure of the cell wall of Micromonospora spp, which impedes the release of the antibiotic from the cell into the broth. However, the release of gentamicin increases from 38.3 to $75.8 \%$, when off-line ultrasonic treatment is utilised. However, the increase of secretion slowed down at $108 \mathrm{~h}$ of fermentation, but still resulted in $42 \%$ more product in the broth. After further ultrasonic treatment the secretion of GM was increased 3.8 times over the control, suggesting that the release of GM into the broth could alleviate the feedback regulation of GM biosynthesis (Chu et al., 2000).

\section{US and Enzymatic Hydrolysis of Biopolymers}


Considerable recent effort has been expended in the use of ultrasound in conjunction with enzymes to try and maximise the amount of glucose and hence ethanol production from cellulosic materials. Some processes encompass enhanced fermentation while others increase the amount of available substrates from biopolymers. The following discussion does not include studies where samples have been sonicated prior to addition of enzymes rather than simultaneous treatments.

A seminal paper in this area was published in 1997 and described the ultrasonic stimulation of ethanol production during simultaneous saccharification and fermentation (SSF) of office paper (Wood et al., 1997). The commercial production of ethanol from cellulose is prevented in part by the high cost of fungal cellulase enzymes. However, intermittent exposure of SSF processes to ultrasonic energy was found to increase ethanol production from mixed office paper waste by around $20 \%$. Without ultrasound twice as much enzyme was required to obtain the same results. Not surprisingly, continuous exposure of the enzymes to ultrasound resulted in decreased ethanol production due to microbiostatic effects. A kinetic study of the enhancement of hydrolysis of cellulosic materials with continuous ultrasonic irradiation has been described by Li et al. (2004). A simplified kinetic model of the hydrolysis was proposed by considering the system as being pseudo-homogeneous and considering the concentration of sugar to be constant at the final level. The validity of the model was confirmed by simulation of the production of total sugar and glucose over time during the saccharification either with or without ultrasonic irradiation $\left(20 \mathrm{kHz}\right.$ at $45^{\circ} \mathrm{C}$ ). It was found that with an irradiation intensity of $15 \mathrm{~W}$ the saccharification rate was enhanced by 2-3 times depending on the nature of the substrate pulp. Further increase in wattage did not lead to higher (or indeed lower) saccharification.

In related work the effects of ultrasonic intensity and reactor scale on the kinetics of enzymatic saccharification of various waste papers were studied ( $\mathrm{Li}$ et al., 2005). The ultrasonic saccharification was less effective on the larger scale probably due to a decrease in ultrasonic intensity per reaction volume. Most waste papers were more efficiently hydrolysed with cellulase (Meicelase from Trichoderma viride), but ultrasonic treatment of newspaper proved to be problematic due to the presence of lignin impurities.

Ultrasonic energy can enhance liquefaction and saccharification of corn slurry both by pre-treatment (due to a 20fold reduction in particle size) and, crucially, contemporaneously with enzymes. Enzyme addition during sonication gave higher glucose yields than enzyme addition after ultrasound $(20 \mathrm{kHz})$ 
treatment. In addition, the authors report glucose release was 30\% higher when subjected to sonication probably due to a decrease in particle size, better mixing due to streaming effects and release of additional lipid-bound starch. However, there is a limit for the amount of ultrasonic energy that can be applied - high energy input and longer sonication times resulted in a $60 \%$ decrease in glucose release due to enzymes being denatured. Interestingly, energy calculations indicated that 2 times the sugar energy equivalent was obtained for every Joule added indicating that integration of ultrasonics and dry milling may significantly improve ethanol yield and efficiency (Khanal et al., 2007). In a closely related study carried out using cassava chip slurry as feedstock the reducing sugar release was as high as $180 \%$ of the control samples and the slurry samples with enzyme addition during sonication resulted in greater release than samples with enzyme addition after sonication. It was found that heat generated during sonication did not account for the increased reducing sugar release (Nitayavardhana et al., 2008).

The production of bio-ethanol from lignocellulosic materials is currently impeded by the high cost and low efficiency of enzymatic hydrolysis and plant cellulase activity. However, on a laboratory scale, this can be partly overcome by the introduction of low energy ultrasound (using a $50 \mathrm{kHz}$ ultrasound hexagon reactor system; 50 ${ }^{\circ} \mathrm{C}$ ) during the enzymatic hydrolysis of corn stover and sugar cane bagasse where the enzyme efficiency greatly improves. The general stages of an enzymatic reaction on a solid substrate are shown in Figure 7 (Yachmenev et al., 2009).

1. Transfer of enzyme macromolecules from aqueous phase to the surface of the solid substrate

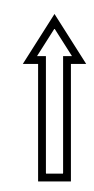

4. Transfer of the hydrolytic reaction products (sugars) to the aqueous phase
2. Adsorption or "locking" of enzyme macromolecules onto the surface of the substrate

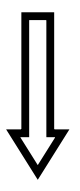

3. Catalysis of surface hydrolytic reactions by specific enzyme macromolecules 
Figure 7. Schematic diagram of the general stages of an enzymatic reaction on a solid substrate. (Adapted from Yachmenev et al. 2009).

Yachmenev et al. (2009) suggest that the use of combined enzyme/ultrasound bioprocessing resulted in: (a) cavitation effects enhancing the transport of enzyme macromolecules to the surface of the substrate; (b) opening up of the substrate surface to the action of enzymes as a result of mechanical impact of cavitation; (c) cavitation being enhanced in heterogeneous systems; and (d) optimum enzyme temperature of $50^{\circ} \mathrm{C}$ coincides with maximum cavitation .

A recent report on the effect of different ultrasonic frequencies on the enzymatic hydrolysis of cellulose indicates that $20 \mathrm{kHz}$ and $28 \mathrm{kHz}$ are much more effective than $500 \mathrm{kHz}$ (Yasuda et al., 2010). For the lower frequency ultrasonic irradiation the total sugar concentration increased linearly with ultrasonic intensity but the opposite was observed with a $500 \mathrm{kHz}$ plate-type transducer.

There has been considerable debate regarding the use of foodstuffs as input for production of ethanol. A more abundant and morally justifiable feedstock is waste cellulosic material such as lignocellulose and ultrasound has been shown to enhance its conversion into bio-ethanol. Thus, Rolz (1986) reported that use of ultrasound $\left(20 \mathrm{kHz} ; 40{ }^{\circ} \mathrm{C}\right)$ during enzymatic saccharification enhanced the rate and extent of reaction of sugarcane bagasse, that had previously been pretreated with ultrasound, by over 200 $\%$. It was suggested that ultrasound influenced the dynamic adsorption-desorption enzyme mechanism due to acoustic streaming and local micro-turbulence. The effect was only observed in substrates which had an open or swollen matrix and partial delignification.

The hydrolysis of cellulose from biomass (lignocellulose) with just an enzymatic process is rather slow but continuous irradiation with ultrasound has been investigated in order to: (a) understand the interaction between the enzyme and the substrate; (b) study the effect of lignin on the hydrolysis; and (c) examine the applicability of a kinetic model (Nakao et al., 1990). These researchers concluded that ultrasound $\left(20 \mathrm{kHz} ; 45^{\circ} \mathrm{C}\right)$ enhanced saccharification due to significant delignification caused by loosening of the network allowing access by the enzyme. However, ultrasound had little effect on the conversion of oligosaccharides into reducing sugars.

A patent related to the above published work has been granted (Ingram and Wood, 2001) and presents a method for improving enzymatic degradation of lignocellulose through the use of ultrasonic treatment at a frequency between 2 and $200 \mathrm{kHz}$ and 
$30-48{ }^{\circ} \mathrm{C}$ ). The cellulase requirements are reduced by around $50 \%$ and so the cost-effectiveness of the process is enhanced. It was also reported that continuous irradiation results in a decrease in hydolysis compared to discontinuous application of ultrasound probably due to the fact that constant mixing does not allow the cellulase to rebind to cellulose long enough for catalysis to occur.

\section{Enhancement of Anaerobic Digestion by US}

Anaerobic digestion (AD) has been used for many decades as the most universally applied technology for stabilisation of sludge in waste water treatment plants (Tiehm et al., 1997). It owes its popularity in the wastewater industry to a number of qualities, most notably the generation of methane (biogas) as the main end product. Anaerobic digestion is a biologically complex process and degradation of organic matter under anaerobic conditions proceeds through four principal reaction steps: hydrolysis, acidogenesis, acetogenesis and methanogensis. Each of the major metabolic processes is carried out by a mixture of bacterial species whose presence will depend on the timeline in the reactor (Chen et al., 2008a) and influent characteristics (Angelidaki and Sanders, 2004) of the digester. However, in general, anaerobic digestion is very slow and sensitive to changes in environmental conditions (McCarty, 1964). Therefore, for many years, researchers in the sludge digestion field have effectively applied ultrasonic waves to improve the efficiency of anaerobic digestion processes, resulting in increased methane production and considerable reduction of digestion time (Gogate and Kabadi, 2009, Pilli et al., 2010).

US has two main effects on anaerobic digestion. Firstly, there is enhanced anaerobic sludge digestion by physical disintegration of organic structures or extraction of substances (Neis et al., 2001). The other approach uses US to encourage enzymatic activity and to improve overall performance of the anaerobic digestion process (Liu et al., 2005b, Liu et al., 2005). The majority of research has predominantly focused on the destruction of organic matter by US treatment (Tiehm et al., 2001, Onyeche et al., 2002, Wang et al., 2006, Nickel and Neis, 2007, Show et al., 2007, Laurent et al., 2009, Pérez-Elvira et al., 2010), thereby enhancing the hydrolysis process. In contrast, very little attention has been dedicated to investigate the effects of US to enhance activity of microorganisms (Schläfer et al., 2000).

Proteins, polysaccharides and lipids (70-80\%) are the main organic species found in sewage sludge and large proportions (30$85 \%$ ) of these exist as particles larger than $0.1 \mu \mathrm{m}$, which microorganisms cannot assimilate. For this reason, bacterial enzymes are required to hydrolyze them into smaller units which 
are released into the media before subsequent degradation (Frølund et al., 1995, Toerien and Hattingh, 1969). Therefore, at the core of anaerobic degradation treatment is a number of biochemical reactions stimulated by enzymes. Aminopeptidases, dehydrogenases, galactosidases, glucosidases, lipases and phosphatases represent the main hydrolytic enzymes which have been identified in sludge and are released during aerobic and anaerobic digestion processes in varied proportions. Normally, enzymes are attached to sludge flocs (extracellular polymeric substances) or to cell walls (by ionic and hydrophobic interactions), consequently free enzymatic activity is very low (Nabarlatz et al., 2010). Additionally, as well as the level of concentration, the location of the enzymes within the cell and product transport mechanisms dictate the rate of release and thus the overall rate of biological reactions.

Ultrasonic pre-treatment can also increase the activity of a number of enzymes by shifting the interacting species from within the sludge flocs to outside so that digestion efficiency is greatly improved. An ultrasonic treatment time of $10 \mathrm{~min}$, density of 3 $\mathrm{W} / \mathrm{mL}$ and frequency of $20 \mathrm{kHz}$ at $25^{\circ} \mathrm{C}$, led to 7 times more activity of enzymes in the outer layer (excluding a-amylase - the activity of which only increased by 2.2 times), with little enzyme inactivation, which surprisingly, was also seen during ultrasonic pretreatment. On the contrary, there was a marked enhancement of enzymatic activities related to ultrasonic pre-treatment time and power density (Yu et al., 2008).

Studies have shown that low power ultrasonic treatment can increase microbial activity and thus can be used to augment bioremediation of wastewater. If the ultrasonic power is too low, it may not have any effect on bioactivity, whereas if the intensity of ultrasound crosses a certain threshold, cavitation may arise and cell death ensues (Liu et al, 2005a; Xie et al, 2009). Generally, it is believed that ultrasonic treatment with intensities larger then 10 $\mathrm{W} / \mathrm{mL}$ can be detrimental to biomolecules (Bougrier et al, 2005). For example, Nabarlatz et al. (2010) have reported maximal extraction of protease and lipase during ultrasonic treatment at intensity of $3.9 \mathrm{~W} / \mathrm{mL}$ and US frequency of $24 \mathrm{kHz}$ at $5 \pm 1{ }^{\circ} \mathrm{C}$ ). However, no increase in the quantity of activated enzymes with higher acoustic power was observed. In addition, it was shown that US produced the same amount of protease (52.9 units/g VSS) and almost 50\% more lipase (21.4 units/g VSS) in just 10-20 min of extraction compared to merely stirring, saving time and power (8.3$16.7 \times 10^{-3} \mathrm{kWh}$ to $50 \times 10^{-3} \mathrm{kWh}$ ) during the process.

The use of low-intensity US on anaerobic sludge activity and the effectiveness of the anaerobic wastewater treatment process have also been successfully demonstrated. The biological activity of anaerobic sludge increased dramatically under an optimal ultrasonic 
intensity of $0.2 \mathrm{~W} / \mathrm{mL}$ and low frequency of $35 \mathrm{kHz}$. The irradiation time strongly regulated the activity of the anaerobic sludge; after $10 \mathrm{~min}$., the biological performance of the sludge reached the highest value, but as the irradiation time was extended, it declined gradually. It was suggested that the low-intensity US weakened the cell wall/membrane promoting permeability and selectivity and accelerating nutrient transport (Xie et al., 2009).

Guo et al. (2010a) investigated the effect of US treatment of anaerobic digestion on bio-hydrogen production using glucose as a substrate. The optimal ultrasonic conditions were determined using rational experimental design (Figure 8 ) and showed that production of hydrogen could be increased 1.3 times if US was applied directly to the sludge and 1.5 times if the solution was sonicated for $10 \mathrm{~s}$ at an intensity of $130 \mathrm{~W} / \mathrm{L}$.

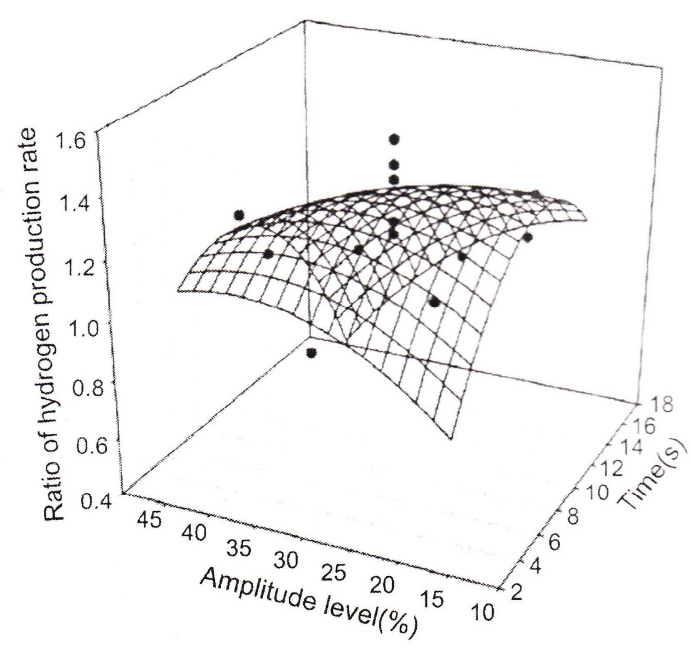

Figure 8: Response plot showing the effects of ultrasonic time (s) and amplitude level (\%) on the ratio of hydrogen production (from Guo et al., 2010)

Effective US stimulation of microbiological populations are observed only for ultrasonic intensities within a very narrow range (Schläfer et al., 2002). No meaningful stimulation of enzymatic activity was demonstrable when ultrasound power below $0.5 \mathrm{~W} / \mathrm{L}$ or above $2 \mathrm{~W} / \mathrm{L}$ was used. Very high microbiological activity was seen between 1-2 W/L, with the maximum productivity observed at an optimum US intensity of $1.5 \mathrm{~W} / \mathrm{L}$ at a frequency of $25 \mathrm{kHz}$. Interestingly, higher US power released different enzymes whereas lower US duration merely caused higher activities of the same enzymes (Yu et al., 2009). Additionally, Zhang et al. (2008) found that low frequency US $\left(25 \mathrm{kHz} ; 20 \pm 2{ }^{\circ} \mathrm{C}\right)$ improved the microbial activity more effectively than slightly higher frequency ( 80 and 150 $\mathrm{kHz}$ ), assigning the main mechanism for promoting enzymatic 
activity to mechanical effects. A frequency of $25 \mathrm{kHz}$, power density of $0.2 \mathrm{~W} / \mathrm{mL}$ for $30 \mathrm{sec}$ increased sludge oxygen utilization rate $(28 \%)$, biomass growth rate $(12.5 \%)$, chemical oxygen demand and total nitrogen removal efficiency (5-6\%) and were the most favourable experimental conditions in their tests. The authors suggested that these positive effects were a result of ultrasound improving mixing, phase transfer and cell membrane permeability resulting in an acceleration of growth of the microorganisms in the sludge. Lin and Wu (2002) considered that the increase in biological activity may be a consequence of self-defence mechanisms as a result of mechanical stresses (biotic and abiotic) occurring during US treatment.

Interestingly, Schläfer et al. (2000) and Liu et al. (2005a) found that the level of enzymatic activity remained high even some hours after irradiation was stopped. It was found that the peak level of enzymatic activity in sludge was seen 8 hours after the US was stopped, After $24 \mathrm{~h}$ US irradiation $(35 \mathrm{kHz} ; 0.3 \mathrm{~W} / \mathrm{mL}$ and irradiation time of $10 \mathrm{~min}$ ), the enhancement effects induced by ultrasound disappeared (Liu et al., 2005a). Additionally, better ultrasound-mediated degradation was achievable by discontinuous rather than continuous ultrasonic treatment (Schläfer et al., 2000) indicating that only some steps in the metabolic pathways are enhanced while others are inhibited (Chiu et al., 1997).

Low energy ultrasonic treatment $(0.05-0.1 \mathrm{~W} / \mathrm{mL}$ at $25 \mathrm{kHz}$; $20 \pm 2{ }^{\circ} \mathrm{C}$ ) can increase sludge microbial activity and more importantly, its improvement is related to the degree of sludge disintegration. The biggest increase (20-40\%) in microbial activity, was recorded when sludge disintegration degree was very small (up to $20 \%$ ). whereas radical decline of microbial activity was observed when the disintegration degree of sludge was over $40 \%$. The highest microbial activity was achieved when the micro-floc aggregates were disconnected from sludge flocs and the transportation of oxygen and nutrients was observed. In the later stages of treatment, the microorganisms were damaged gradually by ultrasound although microbial activity still increased due to further improvement in mass transfer, up to a point where further ultrasonic cavitation damaged the cells and sludge activity decreased drastically. Therefore, in sonicated sludge inactivation and activation mechanisms must occur simultaneously, and their holistic effect depends upon various ultrasonic conditions (Huan et al., 2009).

Most of the studies described above have been carried out in order to enhance rates of hydrolytic enzyme catalyzed reactions by US treatment. However, Kim and Lee (2005) have investigated the effect of US on the digestion process of anaerobic granules by stimulating methanogenesis. They demonstrated that US treatment produced a high concentration of carbohydrates and the methane 
production rates were virtually doubled. The values obtained in the specific methanogenic activity test (SMA) increased from $26 \%$ to $84 \%$ at one site and $163 \%$ to $220 \%$ at another. The authors suggested that an ultrasonic power of $5 \mathrm{~W} / \mathrm{L}$, at a frequency of 40 $\mathrm{kHz}\left(35^{\circ} \mathrm{C}\right)$ and irradiation time of $5 \mathrm{~min}$, may prove to be a cost effective treatment technology. Similar research outcomes were seen by Xie et al. (2009) who found that US treatment of the anaerobic process may lead to significant reduction of bioreactor volumes though a large number of factors including temperature, dissolved gasses, suspended particles, structures and metabolism of microorganisms are involved (Farooq et al., 2009). Therefore, proper design and operation of ultrasound enhanced sonobioreactors are very important parameters and this has been reviewed (Chisti, 2003). However, more studies on how ultrasonic treatment can enhance microbial activity in the anaerobic digestion process are required.

\section{US Stimulation of Enzymes in Food Science and Technology}

The application of ultrasound in the food industry has been reviewed by Mason et al. (1996) and they describe its use in freezing, sterilisation, extraction, and drying as alternatives for nonthermal processing of food. In addition, sonication has been used in emulsification, dispersion and crystallisation processes but little work has been reported on the application of ultrasound in conjunction with bio-processes in food science and technology. Lactose-hydrolysed yogurt has improved nutritional value for lactose-intolerant people and it can be prepared by sonication during the course of fermentation (Toba et al., 1990). Milk was inoculated with Lactobacillus delbrueckii or $L$ helveticus, incubated for $4 \mathrm{~h}$, sonicated $\left(20 \mathrm{kHz} ; 60 \mathrm{~W} ; 0{ }^{\circ} \mathrm{C}\right)$ and then incubated for an additional $12 \mathrm{~h}$. Sonication resulted in $71-74 \%$ depletion in the initial lactose whereas only 39-51\% lactose hydrolysis was obtained from non-sonicated milk (Figure 9). 


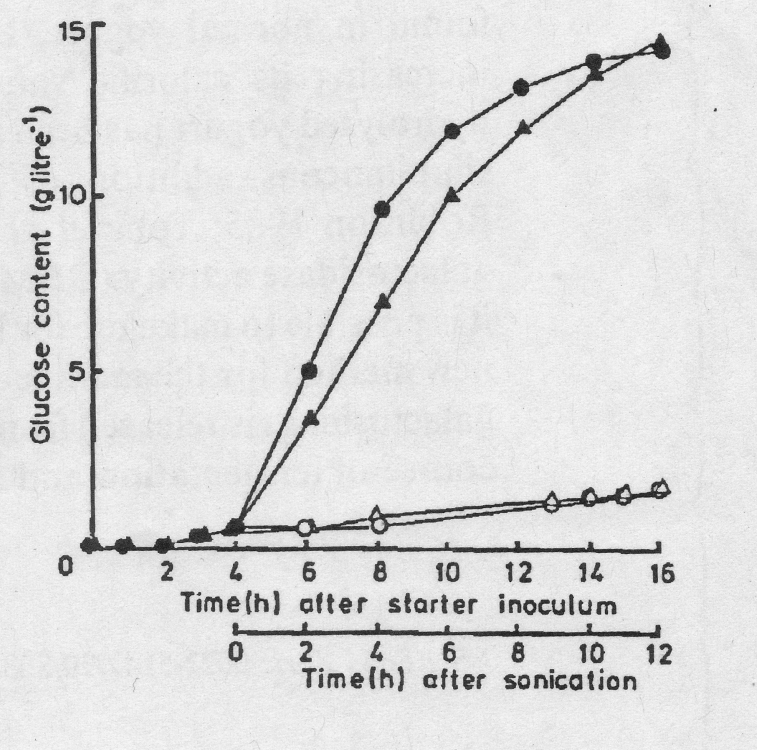

Figure 9: Effect of post-sonication incubation time on the release of glucose. L. delbrueckii - sonicated $(\boldsymbol{\Delta})$, not sonicated $(\triangle) ; L$. helveticus sonicated $(\bullet)$, not sonicated $(0)$ (From Toba et al., 1990)

Wang and co-workers have also examined the effect of ultrasonic irradiation on milk fermentations. Using L. delbrueckii along with ultrasound, the extent of hydrolysis of lactose was $55 \%$ compared to $36 \%$ in the control fermentation. During sonication the cell viability decreased but increased again when the ultrasound was stopped indicating that cell reproductive capability was not impaired (Sakakibara et al., 1994). Later work concentrated on cell viability, beta-galactosidase activity, $\mathrm{pH}$ of the culture medium, degree of lactose hydrolysis and glucose content. Ultrasonic irradiation caused intracellular beta-galactosidase to be released from the lactic acid bacterial cells and this enzyme showed higher lactose hydrolysis compared to that found within the cells. The overall conclusion was that a high degree of lactose hydrolysis and elevated cell viabilities were obtained with the combination of $\mathrm{pH}$ controlled sonicated fermentation and static incubation (Wang et al., 1996). When milk fermentation with four Lactobacillus strains was carried out under sonication $\left(200 \mathrm{kHz} ; 37 \pm 0.2^{\circ} \mathrm{C}\right)$ it was found that with three of the strains the degree of lactose hydrolysis achieved was around $75 \%$ which is much higher than the $40 \%$ obtained from conventional fermentation (Wang and Sakakibara, 1997). Related work on modelling of milk lactose hydrolysis and $\beta$ galactosidase stability under ultrasonic treatment showed that lactose hydrolysis in milk was very high at $90 \%$ while enzyme loss of activity was only $25 \%$. This showed that ultrasonic irradiation did not seriously affect enzyme stability when $20 \mathrm{kHz}$ ultrasound 
was used at between 20 and $100 \mathrm{~W}$ at a temperature of $37 \pm 1{ }^{\circ} \mathrm{C}$ (Sener et al., 2006). In a closely related report the effect of sonication on hydrolysis of whey lactose and $\beta$-galactosidase stability was studied. Almost identical results were observed for whey as discussed above for milk (Demirhan and Ozbek, 2009).

The effect of $20 \mathrm{kHz}$ ultrasound between $30^{\circ} \mathrm{C}$ and $40{ }^{\circ} \mathrm{C}$ on the fermentation of four strains of Bifidobacterium in milk has been reported (Nguyen et al., 2009). Ultrasound under the applied conditions could decrease the fermentation time for three of the four samples. At the end of the fermentation the viability of the three strains was comparable to that of controls. The US had the effect of rupturing the probiotic cells releasing $\beta$-galactosidase which promoted hydrolysis of lactose and trans-glycosylation. Furthermore, the ultrasound enhanced the growth of the remaining bacterial cells. The lower the concentration of lactose, the higher the amount of oligosaccharides found in the ultrasonically stimulated fermented milk.

\section{Use of Ultrasonically Stimulated Enzymes in Synthesis}

The use of enzymes in organic synthesis is an exceptionally important process particularly when chiral molecules are required. As discussed above, sonication of an enzymatic process can exhibit enhanced biotransformation and this is also true for enzyme mediated organic synthesis. Thus, ultrasonic irradiation $(20 \mathrm{kHz})$ of resting cells of Rhodococcus erthyropolis was investigated for the oxidation of cholesterol to cholestenone (Bar, 1988). Initially, the ultrasonic intensity was optimized to ensure the structural integrity whilst maintaining metabolic activity. Considerable enhancement in the rate of biotransformation of cholesterol was seen for microbial slurries of 1.0 and $2.5 \mathrm{~g} / \mathrm{L}$ of substrate when sonicated for only $5 \mathrm{~s}$ every $10 \mathrm{~min}$ at a power level of $2.2 \mathrm{~W} / \mathrm{mL}$. Surprisingly, ultrasound had no effect on the enzymatic oxidation using cholesterol oxidase. It was suggested that ultrasound irradiation increased the dissolution rate of the cholesterol crystals and more importantly, the enhancement of mass transfer inside and outside of the cell (Figure 10). 


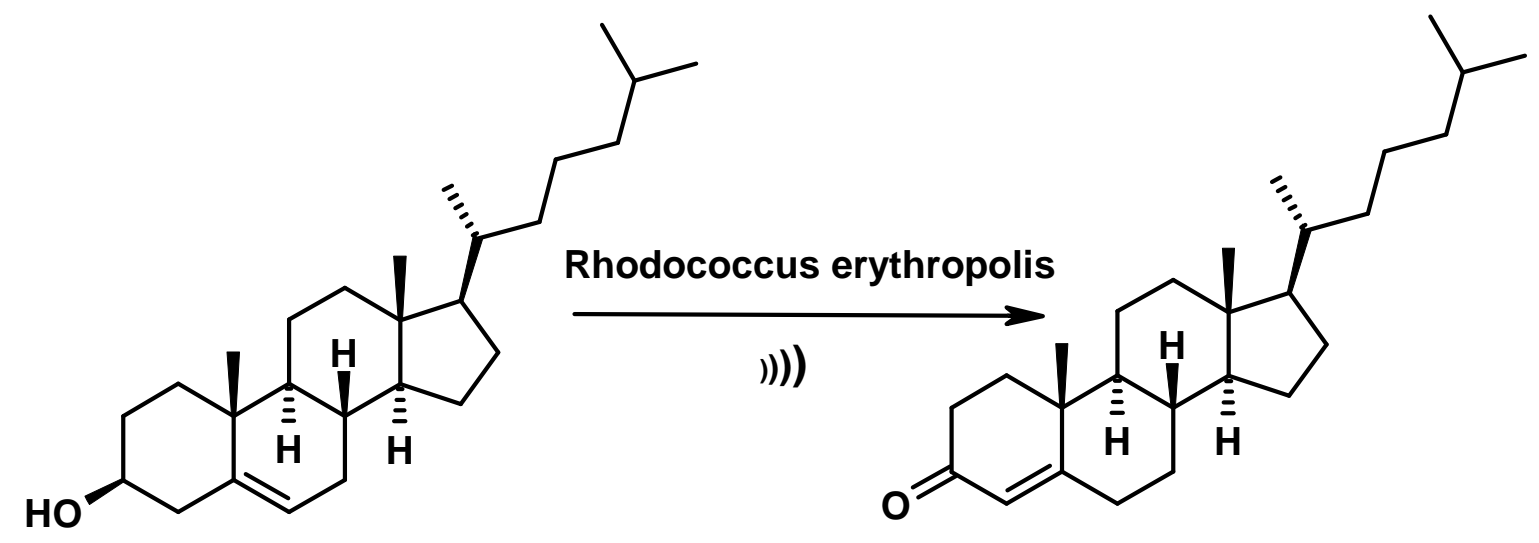

Figure 10: Ultrasonic enhancement of the bioconversion of cholesterol to cholestenone

Related steroid reactions were also stimulated by sonication at $20 \mathrm{kHz}$. Different power densities were applied to the dehydrogenation of hydrocortisone (at two different masses) but only moderate enhancement of the bioconversion by free cells was seen due to dispersal of clumps of cells and self-adhering clusters of steroid. However, a significant stimulation was observed when gelentrapped cells were used as a result of the phonophoretic effect (the movement through boundaries caused by ultrasound) on transport of oxygen and hydrocortisone in the gel beads (Zabaneh and Bar, 1991).

Lipase catalysed acylations and transacylations are very popular methodologies for asymmetric synthesis but the reaction rates are generally very low. However the application of US produces a huge increase in rate when an ultrasonic bath (rather than a probe) is utilised (Lin and Liu, 1995). Porcine pancreatic lipase (PPL) catalyses the hydrolysis of (R)-1,2,3,4-tetrahydro-1naphthyl- butyrate from its racemate to produce $(R)-1,2,3,4-$ tetrahydro-1-naphthol in high stereoselectivity (Figure 11).

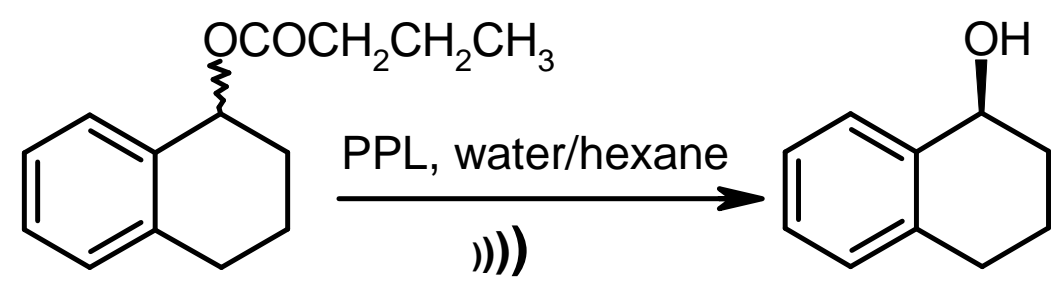

racemic

$(\mathrm{R})$

Figure 11: Ultrasonic hydrolysis of racemate to give high stereoselectivity. 
When an ultrasonic probe $(20 \mathrm{kHz})$ was utilised the rates and stereo-selectivities decreased compared to the control probably due to enzyme denaturation because of local high temperature (not recorded). However, reaction rates increased 7 times and stereoselectivity was the same as the control if an ultrasonic bath was used at a temperature of $33^{\circ} \mathrm{C}$. An even more startling increase in rate was seen on PPL-catalysed acylation of racemic-1,2,3,4tetrahydro-1-naphthol in benzene/ether as solvent. Although the selectivity remains the same the rate was increased 83 fold if the reaction was carried out in an ultrasonic bath.

Much recent work has examined ultrasonically enhanced enzymatic synthesis in organic solvents with small amounts of water added to generate a two-phase system. Thus, acylation, this time of konjac glucomannan (KGM; a skin conditioner and a natural thickener obtained from the Asiatic tuber Amorphophallus konjac ), has been reported (Chen et al., 2008b) and is compared with just shaking in tertiary-butanol as solvent. Of the 13 enzymes studied, Novozym 435 showed the best activity on KGM whether with ultrasound or shaking, though the former produced the best improvement in the initial reaction rate, yield and degree of substitution when $100 \mathrm{~W}$ power and some added water were studied. Similar results were obtained when ultrasound was used for the lipase-catalysed regioslective acylation of mangiferin (a polyphenolic compound found in mangoes which shows antimicrobial and antioxidant activities) in non-aqueous solvents (Wang et al., 2010b) and in the optimization of caffeic acid phenylethyl ester synthesis (Chen et al., 2011).

The trans-esterification of $\mathrm{N}$-acetylphenylalanine ethyl ester in various alcohols using ultrasound and subtilisin benefited from both pre-treatment and continuous irradiation. Ultrasonic pre-treatment $(20 \mathrm{kHz})$ of subtilisin suspensions produced a considerable enhancement of enzyme activity and the effect depended on the power of sonication and the water content of the reaction medium and was more pronounced in long chain alcohols. Further enhancement in reaction rate was observed when the enzyme was continuously sonicated $\left(20 \mathrm{kHz} ; 38^{\circ} \mathrm{C}\right)$ and this was found to be superior to pre-treatment (Figure 12). Subtilisin was found to be much more resistant to inactivation by ultrasound in organic solvents compared to water (Vulfson et al., 1991) (Figure 13). 


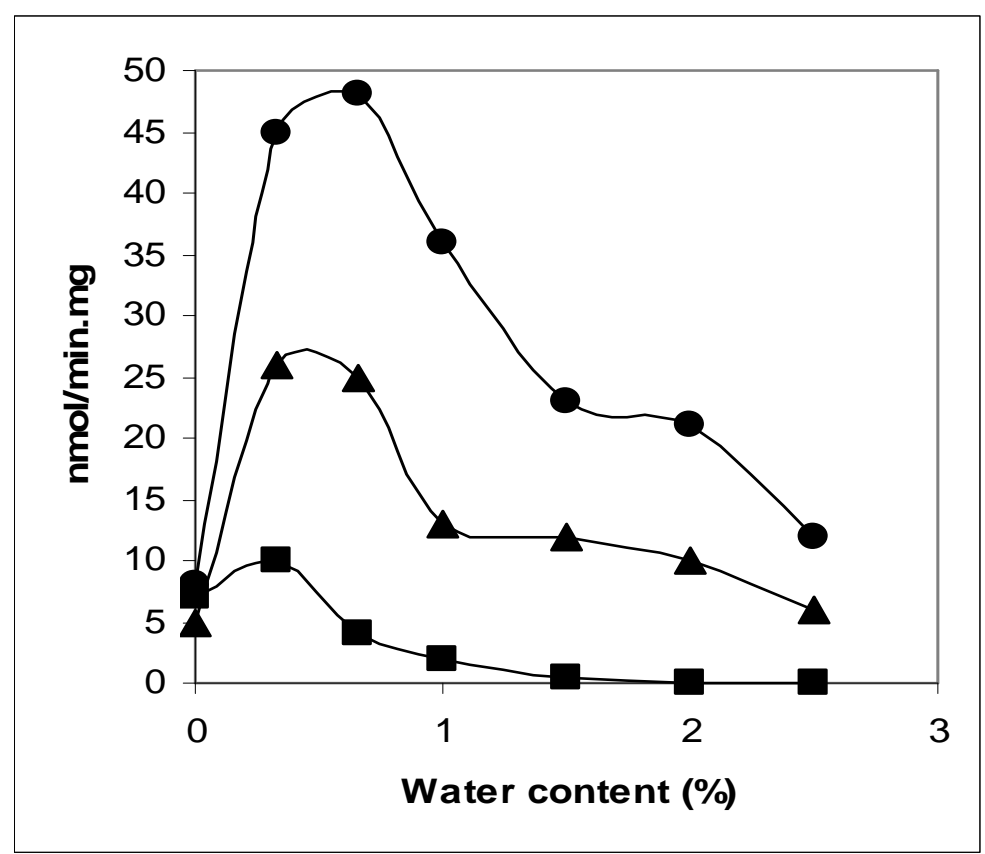

Figure 12: Dependence of ultrasound enhancement on water content in media. Incubation performed in octanol with continuous sonication $(\bullet)$; without sonication but with orbital shaker $(\boldsymbol{\square})$; or after pretreatment with ultrasound followed by shaking $(\mathbf{\Delta})$. (Adapted from Vulfson et al., 1991).

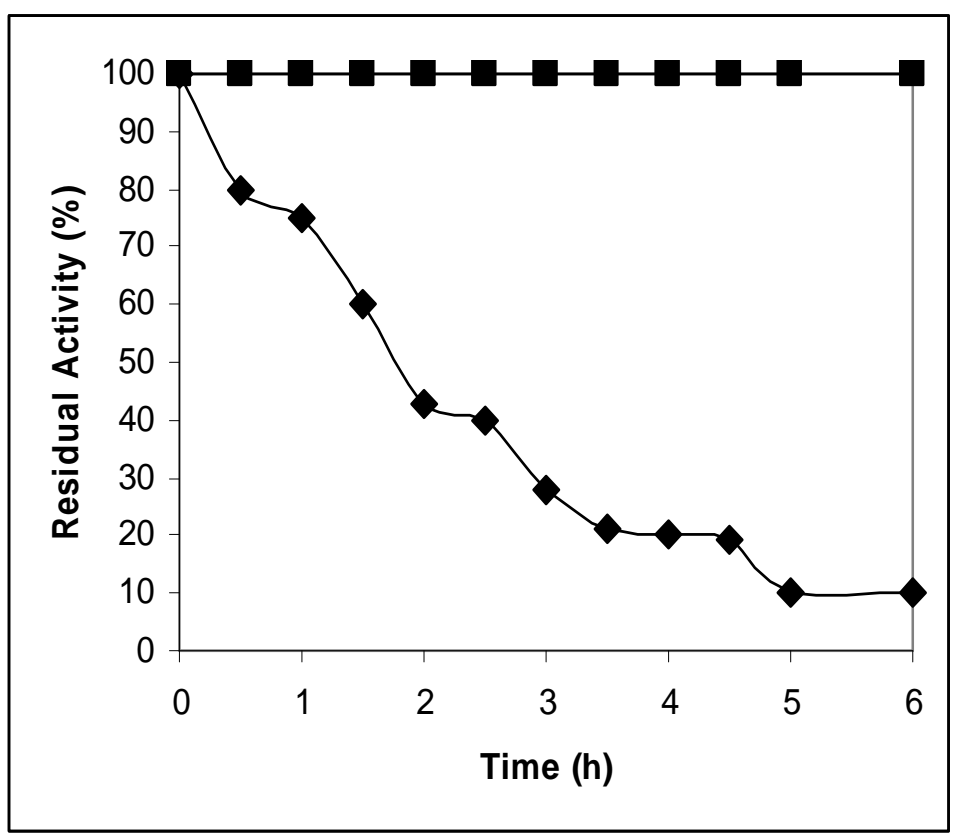

Figure 13: Resistance of subtilisin to inactivation by ultrasound. Phosphate buffer: $50 \mathrm{mM} \mathrm{pH} 7.8$ (diamond $\bullet$ ); t-amyl alcohol containing $1 \%(\mathrm{v} / \mathrm{v})$ of same buffer (square $\mathbf{0})$. (Adapted from Vulfson et al., 1991).

Soybean oil hydrolysis by lipase in a solvent-free system was investigated by using a mechanical stirring bath and an ultrasonic bath $(120 \mathrm{~W} ; 47 \mathrm{kHz})$ at $55^{\circ} \mathrm{C}$. Soybean oil, water and lipase were 
mixed in a conical flask at the desired reaction temperature. The reaction systems were mechanically stirred in a water bath or/and irradiated by ultrasound at the required power. An efficient protocol for diacylglycerol production by the hydrolysis of soybean oil under lipase catalyzed reaction and ultrasound irradiation was developed and it was found that the enzyme could be recycled and even after three cycles good yields were still obtained (Babicz et al., 2010). Enzyme catalysed production of biodiesel can be enhanced considerable by the application of ultrasound $(28 \mathrm{kHz})$. Commercially immobilised lipase (Novozyme 435) was used as a biocatalyst for the trans-esterification of high acid value waste oil and 1-propanol into propyl oleate. The application of US, enhanced enzymatic activity by emulsifying the oil-propanol mixture and accelerating the speed of diffusion. The optimal conditions were found to be $8 \%$ enzyme to oil ratio and a $3: 1$ ratio of propanol to oil at a temperature of $40{ }^{\circ} \mathrm{C}$ and $100 \mathrm{~W}$ sonic power. A yield of $95 \%$ propyl oleate was obtained in 50 min which compares to $84 \%$ for non-sonicated samples. Ultrasound also appeared to decrease the adsorption of the propyl oleate and the by-product glycerol on the enzyme surface thus ensuring easy processing and recycling of the immobilised enzyme (Wang et al., 2007). Similar work has been reported for the lipase-catalysed hydrolysis of soy oil in a solvent free system (Liu et al., 2008). Using an ultrasonic power of $1.64 \mathrm{~W} / \mathrm{mL}$ at $28 \mathrm{kHz}$ and at $40^{\circ} \mathrm{C}$ it was found that satisfactory hydrolysis and lipase stability was obtained and the conditions were optimised with respect to temperature, $\mathrm{pH}$, enzyme concentration and water/soy oil ratio. Compared to results obtained by shaking, the optimum temperature and inactivation temperature of the lipase in the ultrasonic bath was $5-10^{\circ} \mathrm{C}$ higher, while $\mathrm{pH}$ effects were similar and the overall hydrolysis reaction rate was two times that seen in the shaking bath (Figure 14).

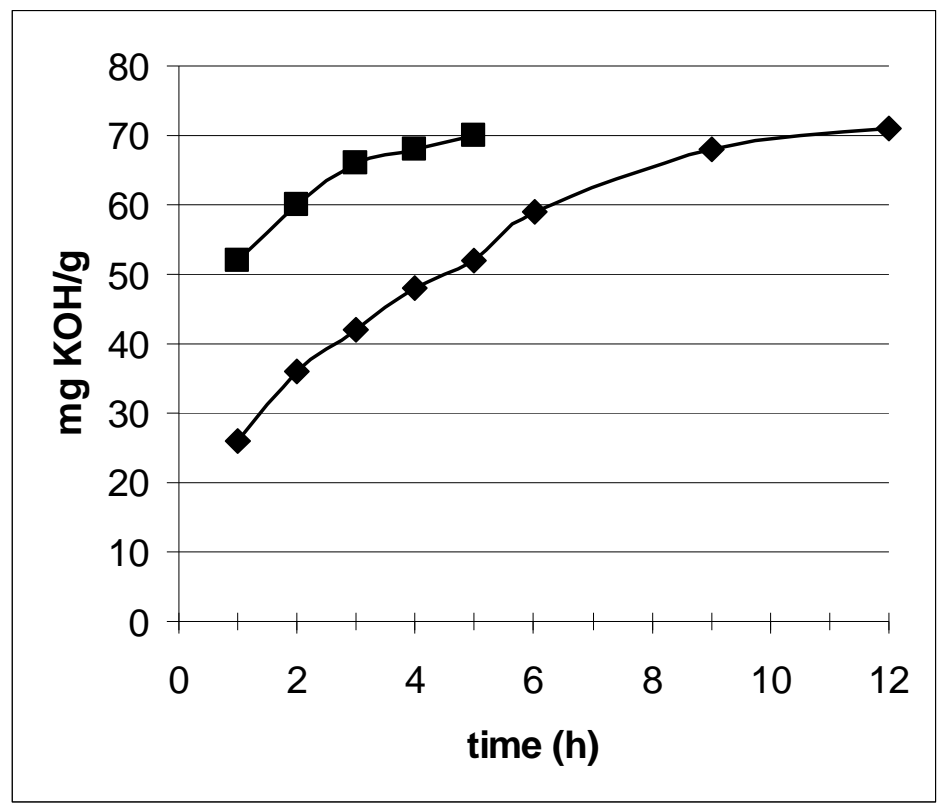


Figure 14: Comparison of soy oil hydrolysis in a shaking bath ( $\bullet$ ) and an ultrasonic bath (ם). (Adapted from Liu et al., 2008)..

A comparison of the hydrolysis of olive oil catalysed by Cromobacterium viscosum lipase in a water/iso-octane two phase system with either stirring or sonication showed that the latter was 1.75 times more effective at $25^{\circ} \mathrm{C}$. The activity of the lipase depended on the ultrasonic power and the amount of water in the isooctane and under optimised conditions the maximum reaction rate was increased by ultrasonication but the Michaelis constant remained the same (Talukder et al., 2006).

Ultrasound enhanced enzymatic synthesis of esters in nonaqueous environments have also been reported. The influence of solvents, enzymes, chain length of the acyl donors, power and intermittency of application of ultrasound (bath) was investigated. Of the eight solvents studied, pyridine was the most effective in conjunction with alkaline protease from $B$. subtilis whether with shaking or sonication. The stimulation of trans-esterification by ultrasound increased with the chain length of the acyl donors and the optimal conditions were $120 \mathrm{~W}$ with continuous irradiation at $50{ }^{\circ} \mathrm{C}$. As is often observed with such treatments, the ultrasound did not change the character and the selectivity of the enzyme in the transesterification (Xiao et al., 2005). In a related study, the synthesis of troxerutin (a type of flavonoid isolated from the japanese pagoda tree being investigated as a vasoprotective agent) esters was reported (Xiao et al., 2011). Using alkaline protease from B. subtilis, which had been ultrasonically pre-treated for $8 \mathrm{~h}$ or continuously sonicated ( 80 $\left.\mathrm{kHz} ; 150 \mathrm{~W} ; 50{ }^{\circ} \mathrm{C}\right)$, the conversion of troxerutin to its ester in pyridine as solvent and divinyl carbonate as donor was increased by $87 \%$ compared to $56 \%$ for the non-sonicated material.

Ionic liquids (ILs) which can dissolve high concentrations of sugars and retain enzyme activity have been reported but the activity of lipases in ILs is usually very low. However, the lipase (Novozyme 435) catalysed esterifications of glucose with vinyl laurate or lauric acid are considerably enhanced by using super-saturated glucose solutions along with sonication (Lee et al., 2008). Figure 15 shows the effect of sonication on the direct esterification with lauric acid as industrially this would be preferred because of the low price of the substrate and the non-toxic by-product (water). At a temperature of $50^{\circ} \mathrm{C}$ the enzyme activity was increased 4.7 times by using supersaturated glucose solution with sonication compared to the conventional method under magnetic stirring. 


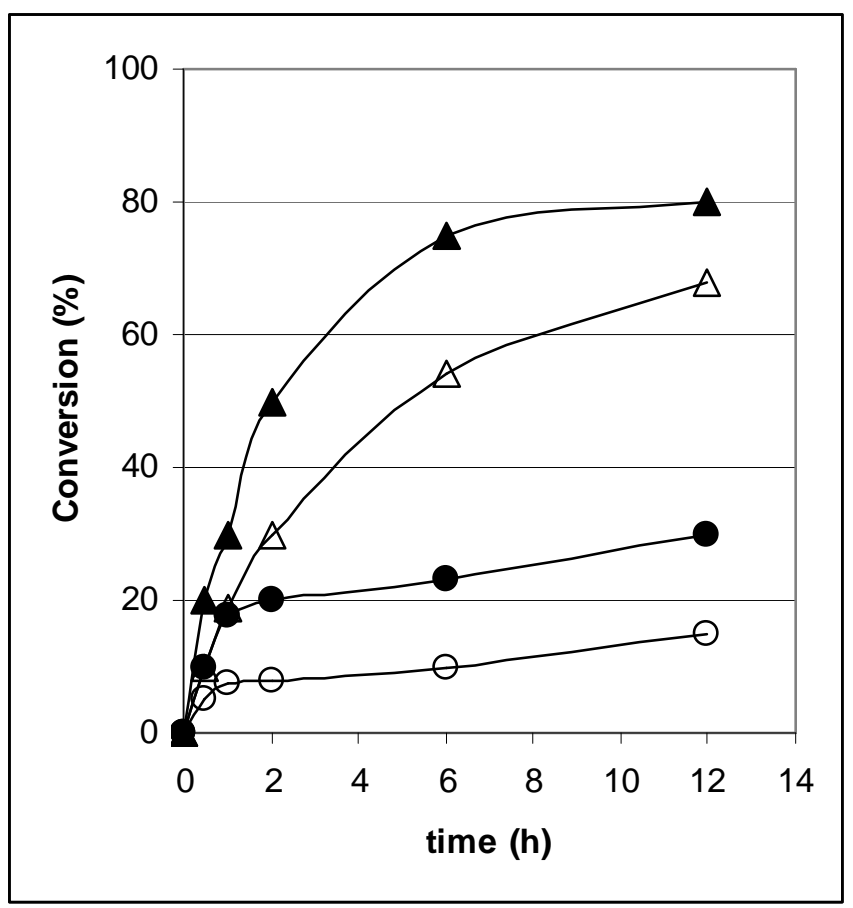

Figure 15: Lipase catalysed direct esterification of glucose in an ionic liquid. Open symbols $(\triangle O)$ represent magnetic stirring only and filled symbols $(\boldsymbol{\Delta} \bullet)$ are magnetic stirring with ultrasound. (circle: saturated solution; triangle: supersaturated solution). (Adapted from Lee et al., 2008).

Although, not strictly applicable to ultrasonic stimulation, one report sheds some light on the possible mechanism for ultrasonic action on enzymes (Shah and Gupta, 2008). Ultrasonic pretreatment (40 kHz; 44, 66 and $110 \mathrm{~W} ; 40{ }^{\circ} \mathrm{C}$ ) of lipases (from Burkholderia cepacia and Pseudomonas fluorescens) in aqueous buffer and organic solvent (octane) increased the rate for the transesterification of ethyl butyrate to butyl butyrate from $66 \%$ to $82 \%$. Similarly, the conversion of Jatropha oil into biodiesel was improved from $34 \%$ (no pre-treatment) to $79 \%$. Circular dichroism spectra and scanning electron microscopic analysis pointed to the fact that the secondary structure of the enzyme was unaltered but the microenvironments of aromatic amino acids and tertiary structure of the enzyme were perturbed.

\section{US and Other Bioprocesses}

There are also a number of diverse examples where sonication can provide increased stimulation of bioprocesses. Ultrasound induces the growth and secondary metabolite biosynthesis of cultured plant cells (Lin et al., 2001). When Panax ginseng cells were exposed to US at a power level of less than 
$85 \mathrm{~mW} / \mathrm{mL}$ for a few minutes in a $38.5 \mathrm{kHz}$ US bath, the total saponin content of the cells was increased by up to $75 \%$. However, the growth and viability of the cells were depressed immediately after exposure to US but this recovered to normal after a few days. The effects on cell growth and metabolite production could be correlated to total US energy inputted. Micro-streaming and mechanical stresses were suggested as the probable causes of the physiological effects observed though they also proposed that secondary metabolite production might have been a result of USinduced plant cell defence response. Similar results were observed for the enhancement of shikonin production from Lithospermum erthrorhizon cell with low energy US (Lin and Wu, 2002).

US can act as an alternative stress on cells or tissues and can stimulate growth and proliferation. US stimulation $\left(28 \mathrm{kHz} ; 25^{\circ} \mathrm{C}\right)$ promoted the growth and proliferation of Oryza sativa Nipponbare callus cells in suspension culture with an optimal treatment of $5 \mathrm{~s}$, while longer exposure inhibited growth and proliferation. It was suggested that enhancement of cell wall and cell membrane fluidity was one of the factors resulting in US stimulation but on longer sonication cellular structure, enzymes and ion channels are affected negatively (Liu et al., 2003a). Further work by the same authors on the growth and vacuolar $\mathrm{H}^{+}$-ATPase activity of aloe Arborescens callus cells confirmed that US could stimulate growth but only as a result of very short periods of exposure (Liu et al., 2003b).

The Monascus pigment is a natural red colouring produced by Monascus spp. However, traditional methods of production result in low yields and afford an impure product from solid fermentation. The culture medium of Monascus spp. was treated with US after 12 $\mathrm{h}$ incubation and was irradiated once every $6 \mathrm{~h}$ for a variety of short periods and then continuously incubated at $28^{\circ} \mathrm{C}$ without US. The results indicated that the US produced a mutant strain which showed a $30 \%$ increase in Monascus pigment production compared to the starting strain (Yang et al., 2005).

Ultrasound $(70 \mathrm{kHz} ;<2 \mathrm{~W} / \mathrm{mL})$ increases the growth rate of bacterial cells attached to polyethylene surfaces. Staphylococcus epidermidis, Pseudomonas aeruginosa and Escherichia coli all showed increased growth compared to non-sonicated cultures probably due to increased rate of transport of oxygen and nutrients to the cells and a higher rate of transport of waste products.

However, at high intensity levels cells were partly removed from the surface (Pitt and Ross, 2003).

Bacterial biofilms growing on implanted medical devices are difficult to eradicate but the application of US enhances the effectiveness of antibiotics used. Quian et al. (1999) have postulated that the mechanism of action is due to US increasing the transport of the antibiotic (gentamicin) through cell membranes by either stimulating active uptake or permitting passive uptake by 
temporarily disrupting the membrane (Quian et al., 1999). Three different methods (US, enzymes, and a combination of both) to standardize biofilm removal for in situ sanitary control of closed surfaces in the food industry were compared. The study utilised an E. coli model biofilm made with milk on stainless steel sheets. Using the combined treatment, the results showed a synergism between the US and the proteolytic or glycolytic enzyme such that $60-90 \%$ of the biofilm was removed. This equated to two or three times greater compared to sonication alone and occurred in $10 \mathrm{~s}$ compared to around 20 min for enzyme alone (Oulahal-Lagsir et al., 2003).

US has been shown to accelerate the enzyme immunoassay of choriogonadotropin (Chen et al., 1984). Binding of the antigen and conjugate to the immobilised phase is often the rate-limiting step in solid-phase immunoassays. US ( $50 \mathrm{kHz}$; nominal $85 \mathrm{~W} ; 25^{\circ} \mathrm{C}$ ) enhances mass transport across liquid/solid interfaces and considerably accelerates antigen binding such that the apparent first-order rate constant for HCG binding is 500 times that of the un-sonicated process. Interestingly, vortex mixing can also accelerate binding but is only one-tenth as effective as US. The authors' explanation for the enhancement is that US reduces the thickness of the diffusion barrier and promotes material exchange across the interface due to both liquid-streaming and cavitation effects.

The need for sensitive and rapid nucleic acid diagnostics is increasingly important in the development of methods for detecting pathogens. The application of $20 \mathrm{kHz}$ US has been shown to generate a preponderance of 100-400 base pairs within several seconds and sample processing can convert $75 \%$ of genomic material to fragments in 20-30 s. Control of salt concentration, exposure time, ultrasonic power and initial temperature can produce a desired average fragment length (Mann and Krull, 2004).

Although not "ultrasound" it is worth considering a report on the effect of audible sound (AS), generated using the equipment shown in figure 16 , on the growth of $E$ coli. Results showed that AS significantly increased the colony forming units of $E$. coli under normal growth conditions. However, under osmotic stress induced by sugar, AS may enhance the inhibitory effect of osmotic stress on growth. More interestingly, AS treatment alleviated the inhibitory effect of salt stress on $E$. coli growth when the concentration of salt was increased to $30 \mathrm{~g} / \mathrm{L}$ but had the opposite effect at $20 \mathrm{~g} / \mathrm{L}$ Suggested mechanisms include AS inducing motion of the cell internal fluid, having a positive effect on water efflux and a rise in influx of sodium ions (Shaobin et al., 2010). 


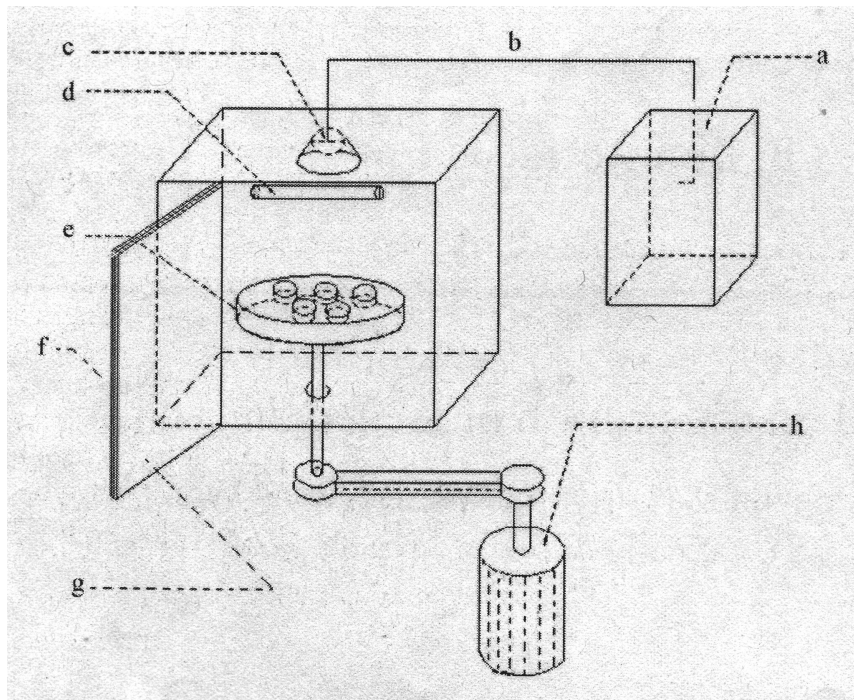

Figure 16: Diagram of sound wave load apparatus; a - wave generation unit; $b$ - sound wave transfer wire; $c$ - speaker; $d$ - UV lamp ( for sterilisation); e - sample holder; $f$ - outer wall of chamber; $\mathrm{g}$ - inner wall with sound absorbing material; $\mathrm{h}$ - motor. (from Shaobin et al., 2010)

\section{Conclusions}

The influence of ultrasound on biological processes has come a long way since Wood and Loomis (1927) reported that red blood corpuscles were rapidly destroyed and small fish and frogs were killed but mice survived for 20 minutes. Undoubtedly high power ultrasound, particularly of $20-40 \mathrm{kHz}$, is damaging to biological molecules both in vivo and in vitro due to the generation of cavitation bubbles which produce a variety of harmful physical effects as well as the production of highly oxidising hydroxyl radicals. However, much recent work has concentrated on the use of sub-lethal doses of ultrasonic irradiation and this has been shown to be extremely beneficial to many bioprocesses. The precise mechanism of action remains to be elucidated and probably varies depending on the substrates involved and the frequency and power of the ultrasound inputted but a variety of observations and plausible mechanistic suggestions have been postulated.

Experiments have shown that US lowers consumption of expensive enzymes, shortening processing times but does not affect the secondary structure of the enzyme although the microenvironments and tertiary structure of the enzyme may be perturbed. In the case of filamentous fungi, US alters morphology and broth rheology without affecting growth. In US enhanced enzymatic synthesis in organic solvents small amounts of added water vastly increase reaction rates.

In the majority of cases the original authors propose a number of mechanisms to explain the observed effects but these are generally 
merely theory rather than based on experimental data. The most common suggestions are that US enhances physical phenomena such as decreasing the unstirred diffusion layer, enhancing emulsification, decreasing particle size, affording better mixing and/or generating micro-streaming and mechanical stress. Other more interesting proposals are that US promotes cell membrane permeability and alters surface potential resulting in activation of calcium channels; weakens the cell wall/membrane promoting permeability and selectivity and accelerating nutrition or molecule transport and/or increases the dissolution rate of moderately soluble compounds and enhances mass transfer inside and outside of the cell. In the case of two phase reactions it is suggested that US lessens the adsorption of organics on the enzyme surface thus ensuring easy processing and recycling of the immobilised enzyme.

Some authors believe that controlled cavitation is not always detrimental and suggest that the use of combined enzyme / ultrasound bioprocessing produces cavitation effects that enhance the transport of enzyme macromolecules to the surface of the substrate which results in the opening up of the substrate surface to the action of enzymes as a result of mechanical impact of cavitation. Furthermore, cavitation is enhanced in heterogeneous systems and the optimum enzyme temperature of $50{ }^{\circ} \mathrm{C}$ coincides with maximum cavitation. There also appears to be certain advantages in the use of discontiuous application of US. For example, it has been observed that during hydrolysis of cellulose, continuous irradiation results in a decrease in hydolysis compared to discontinuous application of US probably due to the fact that constant mixing does not allow the cellulase to rebind to cellulose long enough for catalysis to occur.

To date most of the published research has concentrated on the low frequency US region, but research investigating the higher frequencies of $300 \mathrm{kHz}$ to $2 \mathrm{MHz}$ is beginning to appear with some promising results. This review has shown that work on ultrasonically enhanced bioprocesses is still in its infancy and offers many opportunities for multi-disciplinary research.

\section{References}

ALI KASHKOOLI, H., ROONEY, J. A. \& ROXBY, R. 1980. Effects of ultrasound on acatalase and malate dehydrogenase. $J$. Acoust. Soc. Am., 67, 1798-1801.

ANGELIDAKI, I. \& SANDERS, W. 2004. Assessment of the anaerobic biodegradability of macropollutants. Reviews in Environmental Science and Bio/Technology, 3, 117-129.

APAR, D. K., TURHAN, M. \& OZBEK, B. 2006. Enzymatic hydrolysis of starch by using a sonifier. Chemical Engineering Communications, 193, 1117-1126. 
BABICZ, I., LEITE, S. G. F., DE SOUZA, R. \& ANTUNES, O. A. C. 2010. Lipase-catalyzed diacylglycerol production under sonochemical irradiation. Ultrasonics Sonochemistry, 17, 4-6.

BAR, R. 1988. Ultrasound enhanced processes: Cholesterol oxidation by Rhodococcus erythropolis Biotechnology and Bioengineering, 32, 655-663.

BARTON, S., BULLOCK, C. \& WEIR, D. 1996. The effects of ultrasound on the activities of some glycosidase enzymes of industrial importance. Enzyme and Microbial Technology, 18, 190-194.

BASTO, C., SILVA, C. J., GUBITZ, G. \& CAVACO-PAULO, A. 2007. Stability and decolourization ability of Trametes villosa laccase in liquid ultrasonic fields. Ultrasonics Sonochemistry, 14, 355362.

BOCHU, W., LANCHUN, S., JING, Z., YUANYUAN, Y. \& YANHONG, Y. 2003. The influence of $\mathrm{Ca} 2+$ on the proliferation of $\mathrm{S}$. cerevisiae and low ultrasonic on the concentration of $\mathrm{Ca} 2+$ in the S. cerevisiae cells. Colloids and Surfaces B: Biointerfaces, $32,35-42$.

BREMNER, D. (ed.) 1990. Historical Introduction to Sonochemistry, London: JAI Press Ltd.

CHEN, H. C., CHEN, J. H., CHANG, C. \& SHIEH, C. J. 2011. Optimisation of ultrasound-accelerated synthesis of enzymatic caffeic acid phenethyl ester by response surface methodology. Ultrasonics Sonochemistry, 18, 455-459.

CHEN, R., WENG, L., SIZTO, N. C., OSORIO, B., HSU, C.-J., RODGERS, R. \& LITMAN, D. J. 1984. Ultrasound-accelerated immunoassay, as exemplified by enzyme imunoassay of choriogonadotropin. Clinical Chemistry, 30, 1446-1451.

CHEN, Y., CHENG, J. J. \& CREAMER, K. S. 2008a. Inhibition of anaerobic digestion process: A review. Bioresource Technology, 99, 4044-4064.

CHEN, Z. G., ZONG, M. H., GU, Z. X. \& HAN, Y. B. 2008b. Effect of ultrasound on enzymatic acylation of konjac glucomannan. Bioprocess and Biosystems Engineering, 31, 351-356.

CHISTI, Y. 2003. Sonobioreactors: using ultrasound for enhanced microbial productivity. Trends in Biotechnology, 21, 89-93.

CHIU, Y. C., CHANG, C. N., HUANG, W. S. \& CHAO, A. C. 1997. Effect of ultrasonic and alkaline pretreatment on waste activated sludge characterisation. Journal of Chinese Institute Environmental Engineering., 7.

CHU, J., LI, B. L., ZHANG, S. L. \& LI, Y. R. 2000. On-line ultrasound stimulates the secretion and production of gentamicin by Micromonospora echinospora. Process Biochemistry, 35, 569572.

CHUANYUN, D., BOCHU, W., CHUANREN, D. \& SAKANISHI, A. 2003. Low ultrasonic stimulates fermentation of riboflavin producing 
strain Ecemothecium ashbyii Colloids and Surfaces $B$ :

Biointerfaces, 30, 37-41.

CHUANYUN, D., BOCHU, W., HUAN, Z., CONGLIN, H., CHUANREN, D., WANGQIAN, L., TOYAMA, Y. \& SAKANISHI, A. 2004. Effect of low frequency ultrasonic stimulation on the secretion of siboflavin produced by Ecemothecium Ashbyii. Colloids and Surfaces B: Biointerfaces, 34, 7-11.

DEMIRHAN, E. \& OZBEK, B. 2009. A modeling study on hydrolysis of lactose recovered from whey and -galactosidase stability under sonic treatment. Chemical Engineering Communications, 196, 767-787.

DUNN, F. \& MACLEOD, R. M. 1968. Effects of non-cavitating ultrasound on selected enzymes. J. Accoustical Society of America, 44, 932-940.

ENTEZARI, M. H. \& PETRIER, C. 2004. A combination of ultrasound and oxidative enzyme: sono-biodegradation of phenol. Applied Catalysis B: Environmental, 53, 257-263.

FAROOQ, R., REHMAN, F., BAIG, S., SADIQUE, M., KHAN, S., FAROOQ, U., REHMAN, A., FAROOQ, A., PERVEZ, A., HASSAN, M. \& SHAUKAT, S. F. 2009. The effect of ultrasound irradiation on the anaerobic digestion of activated sludge. World Applied Sciences Journal, 6, 234-237.

FLOSDORF, E. W. \& CHAMBERS, L. A. 1933. The chemical action of audible sound. J. Am. Chem. Soc., 55, 3051-3052.

FLOSDORF, E. W. \& CHAMBERS, L. A. 1935. An Immunological Study of the Effects of Intense Sound Vibrations on Egg Albumin. Journal of Immunology, 28, 297-310.

FRØLUND, B., GRIEBE, T. \& NIELSEN, P. H. 1995. Enzymatic activity in the activated-sludge floc matrix. Applied Microbiology Biotechnology, 43, 755-761.

GOGATE, P. R. \& KABADI, A. M. 2009. A review of applications of cavitation in biochemical engineering/biotechnology. Biochemical Engineering Journal, 44, 60-72.

GOODMAN, L. P. \& DUGAN JR., L. R. 1970. The effect of sonication on lipase activity. Lipids, 5, 362-365.

GUO, Y., KIM, S. H., SUNG, S. H. \& LEE, P. 2010a. Effect of ultrasonic treatment of digestion sludge on bio-hydrogen production from sucrose by anaerobic fermentation. International Journal of Hydrogen Energy, 35, 3450-3455.

GUO, Y. P., KIM, S. H., SUNG, S. H. \& LEE, P. H. 2010b. Effect of ultrasonic treatment of digestion sludge on bio-hydrogen production from sucrose by anaerobic fermentation. International Journal of Hydrogen Energy, 35, 3450-3455.

GUPTA, M. N. \& Roy, I., R. 2004. Enzymes in organic media. Eur. J. Biochem., 271, 2575-2583.

HERRAN, N. S., CASAS LOPEZ, J. L., SANCHEZ PEREZ, J. A. \& CHISTI, Y. 2008. Effects of ultrasound on culture of 
aspergillus terreus. J. of Chemical Technology \& Biotechnology, 83, 593-600.

HUAN, L., YIYING, J., BUX MAHAR, R., ZHIYU, W. \& YONGFENG, N. 2009. Effects of ultrasonic disintegration on sludge microbial activity and dewaterability. Journal of Hazardous Materials, $161,1421-1426$.

INGRAM, L. O. \& WOOD, B. E. 2001. Ethanol production from lignocellulose. United States Patent US 6,333,181.

ISHIMORI, Y., KARUBE, I. \& SUZUKI, S. 1981. Acceleration of immobilised a-chromotrypsin acivity with ultrasonic irradiation. J. Mol. Catal., 12, 253-259.

JIAN, S., WENYI, T. \& WUYONG, C. 2008. Ultrasound-accelerated enzymatic hydrolysis of solid leather waste. J. Cleaner Production, 16, 591-597.

KHANAL, S. K., MONTALBO, M., VAN LEEUWEN, J., SRINIVASAN, G. \& GREWELL, D. 2007. Ultrasound enhanced glucose release from corn in ethanol plants. Biotechnology and Bioengineering, 98, 978-985.

KIM, Y. \& LEE, J. 2005. Effect of ultrasound on methanogenic activity of anaerobic granules. Japanese Journal of Applied Physics, 44, 8259-8261.

LANCHUN, S., BOCHU, W., LIANCAI, Z., JIE, L., YANHONG, Y. \& CHUANREN, D. 2003. The influence of low-intensity ultrasonic on some physiological characteristics of Saccharomyces cerevisiae. Colloids and Surfaces B: Biointerfaces, 30, 61-66.

LAURENT, J., CASELLAS, M., PONS, M. N. \& DAGOT, C. 2009. Flocs surface functionality assessment of sonicated activated sludge in relation with physico-chemical properties. Ultrasonics Sonochemistry, 16, 488-494.

LEE, S. H., NGUYEN, H. M., KOO, Y. M. \& HA, S. H. 2008. Ultrasound-enhanced lipase activity in the synthesis of sugar ester using ionic liquids. Process Biochemistry, 43, 10091012.

LI, C. Z., YOSHIMOTO, M., OGATA, H., TSUKUDA, N., FUKUNAGA, K. \& NAKAO, K. 2005. Effects of ultrasonic intensity and reactor scale on kinetics of enzymatic saccharification of various waste papers in continuously irradiated stirred tanks. Ultrasonics Sonochemistry, 12, 373-384.

LI, C. Z., YOSHIMOTO, M., TSUKUDA, N., FUKUNAGA, K. \& NAKAO, K. 2004. A kinetic study on enzymatic hydrolysis of a variety of pulps for its enhancement with continuous ultrasonic irradiation. Biochemical Engineering Journal, 19, 155-164.

LI, D., MU, C., CAI, S. \& LIN, W. 2009. Ultrasonic irradiation in the enzymatic extraction of collagen. Ultrasonics Sonochemistry, $16,605-609$.

LIN, G. \& LIU, H.-C. 1995. Ultrasound-promoted lipase-catalysed reactions. Tetrahedron Letters, 36, 6067-6068. 
LIN, L. D. \& WU, J. Y. 2002. Enhancement of shikonin production in single and two-phase suspension cultures of Lithospermum erythrorhizon cells using low-energy ultrasound. Biotechnology Bioengineering, 78, 81-88.

LIN, L. D., WU, J. Y., HO, K. P. \& QI, S. Y. 2001. Ultrasoundinduced physiological effects and secondary metabolite (Saponin) production in Panax ginseng cell cultures. Ultrasound in Medicine and Biology, 27, 1147-1152.

LIU, H., HE, Y., QUAN, X., YAN, Y., KONG, X. \& LIA , A. 2005a. Enhancement of organic pollutant biodegradation by ultrasound irradiation in a biological activated carbon membrane reactor. Process Biochemistry, 40, 3002-3007.

LIU, H., YAN, Y., WANG, W. \& YU, Y. 2005b. Improvement of the activity of activated sludge by low intensity ultrasound. Huan Jing Ke Xue (in Chinese), 26, 124-8.

LIU, H., YAN, Y. X., WANG, W. Y. \& YU, Y. Y. 2005. Improvement of the activity of activated sludge by low intensity ultrasound. Huan Jing Ke Xue, 26, 124-128.

LIU, Y. F., YOSHIKOSHI, A., WANG, B. C. \& SAKANISHI, A. $2003 a$. Influence of ultrasonic stimulation on the growth and proliferation of Oryza sativa Nipponbare callus cells. Colloids and Surfaces B: Biointerfaces, 27, 287-293.

LIU, Y. X., JIN, Q. Z., SHAN, L., LIU, Y. F., SHEN, W. \& WANG, X. G. 2008. The effect of ultrasound on lipase-catalyzed hydrolysis of soy oil in solvent-free system. Ultrasonics Sonochemistry, $15,402-407$.

LIU, Y. Y., TAKATSUKI, H., YOSHIKOSHI, A., WANG, B. C. \& SAKANISHI, A. 2003b. Effects of ultrasound on the growth and vacuolar $\mathrm{H}+-$ ATPase activity of aloe arborescens callus cells. Colloids and Surfaces B-Biointerfaces, 32, 105-116.

MACLEOD, R. M. \& DUNN, F. 1966. Ultrasonic irradiation of enzyme solutions. J Accoustical Society of America, 40, 1202-1203.

MANN, T. L. \& KRULL, U. J. 2004. The application of ultrasound as a rapid method to provide DNA fragments suitable for detection by DNA biosensors. Biosensors and Bioelectronics, 20, 945955.

MASON, T. J., PANIWNYK, L. \& LORIMER, J. P. 1996. The uses of ultrasound in food technology. Ultrasonics Sonochemistry, 3, S253-S260.

MCCARTY, P. L. 1964. Anaerobic waste treatment fundamentals. Part 1: Chemistry and Microbiology. Public Works, 95, 107112.

NABARLATZ, D., VONDRYSOVA, J., JANICEK, P., STÜBER, F., FONT, J., FORTUNY, A., FABREGAT, A. \& BENGOA, C. 2010. Hydrolytic enzymes in activated sludge: Extraction of protease and lipase by stirring and ultrasonication. Ultrasonics Sonochemistry, 17, 923-931. 
NAKAO, K., FUKUNAGA, K., YASUDA, Y. \& KIMURA, M. 1990. Enzymatic Hydrolysis of Lignocellulosics with Continuous Irradiation of Supersonic Wave. Annals of the New York Academy of Sciences, 613, 802-807.

NEIS, U., NICKEL, K. \& TIEHM, A. 2001. Ultrasonic disintegration of sewage sludge for enhanced anaerobic biodegradation. Advances in Sonochemistry, 6, 59-90.

NGUYEN, T. M. P., LEE, Y. K. \& ZHOU, W. B. 2009. Stimulating fermentative activities of bifidobacteria in milk by high intensity ultrasound. International Dairy Journal, 19, 410-416.

NICKEL, K. \& NEIS, U. 2007. Ultrasonic disintegration of biosolids for improved biodegradation. Ultrasonics Sonochemistry, 14.

NITAYAVARDHANA, S., RAKSHIT, S. K., GREWELL, D., VAN LEEUWEN, J. \& KHANAL, S. K. 2008. Ultrasound pretreatment of cassava chip slurry to enhance sugar release for subsequent ethanol production. Biotechnology and Bioengineering, 101, 487-496.

ONYECHE, T. I., SCHLÄFER, O., BORMANN, H., SCHRÖDER, C. \& SIEVERS, M. 2002. Ultrasonic cell disruption of stabilised sludge with subsequent anaerobic digestion. Ultrasonics, 40, 31-35.

OULAHAL-LAGSIR, O., MARTIAL-GROS, A., BONNEAU, M. \& BLUM, L. J. 2003. "Escherichia coli -milk" biofilm removal from stainless steel surfaces: Synergism between ultrasonic waves and enzymes. Biofouling, 19, 159-168.

ÖZBEK, B. \& ÜLGEN, K. Ö. 2000. The stability of enzymes after sonication. Process Biochemistry, 35, 1037-1043.

PENA-FARFAL, C., MOREDA-PINEIRO, A., BERMEJO-BARRERA, A., BERMEJO-BARRERA, P., PINOCHET-CANCINO, H. \& DE GREGORI-HENRIQUEZ, I. 2005. Speeding up enzymatic hydrolysis procedures for multi-element determination in edible seaweed. Analytica Chimica Acta, 548, 183-191.

PÉREZ-ELVIRA, S. I., FERREIRA, L. C., DONOSO-BRAVO, A., FDZPOLANCO, M. \& FDZ-POLANCO, F. 2010. Full-stream and partstream ultrasound treatment effect on sludge anaerobic digestion. Water Science \& Technology, 61, 1363-1372.

PILLI, S., BHUNIA, P., YAN, S., LEBLANC, R. J., TYAGI, R. D. \& SURAMPALLI, R. Y. 2010. Ultrasonic pretreatment of sludge: A review. . Ultrasonics Sonochemistry, doi: 10.1016/j.ultsonch.2010.02.014.

PITT, W. G. \& ROSS, S. A. 2003. Ultrasound increases the rate of bacterial cell growth. Biotechnol. Prog., 19, 1038-1044.

QUIAN, Z., SAGERS, R. D. \& PITT, W. G. 1999. Investigation into the mechanism of the bioacoustic effect. Journal of Biomedical Materials Research 44, 198-205.

RADEL, S., MCLOUGHLIN, A. J., GHERARDINI, L., DOBLHOFF-DIER, O. \& BENES, E. 2000. Viability of yeast cells in well controlled 
propagating and standing ultrasonic plane waves. Ultrasonics 38, 633-637.

ROKHINA, E. V., LENS, P. \& VIRKUTYTE, J. 2009. Low frequency ultrasound in biotechnology: state of the art. Trends in Biotechnology, 27, 298-306.

SAKAKIBARA, M., WANG, D. Z., IKEDA, K. \& SUZUKI, K. 1994. Effect of Ultrasonic Irradiation on Production of Fermented Milk with Lactobacillus-DelbrueckiiI. Ultrasonics Sonochemistry, 1, S107-S110.

SCHLÄFER, O., ONYECHE, T., BORMANN, H., SCHRÖDER, C. \& SIEVERS, M. 2002. Ultrasound stimulation of micro-organisms for enhanced biodegradation. Ultrasonics, 40, 25-29.

SCHLÄFER, O., SIEVERS, M., KLOTZBÜCHER, H. \& ONYECHE, T. I. 2000. Improvement of biological activity by low energy ultrasound assisted bioreactors. Ultrasonics, 38, 711-716.

SCHMIDT, P., ROSENFELD, E., MILLNER, R., CZERNER, R. \& SCHELLENBERGER, A. 1987a. Theoretical and experimental studies on the influence of ultrasound on immobilized enzymes. Biotechnology and Bioengineering, 30, 928-935.

SCHMIDT, P., ROSENFELD, E., MILLNER, R. \& SCHELLENBERGER, A. $1987 \mathrm{~b}$. Effects of ultrasound on the catalytic activity of matrix-bound glucoamylase. Ultrasonics, 25, 295-299.

SENER, N., APAR, D. K. \& OZBEK, B. 2006. A modelling study on milk lactose hydrolysis and beta-galactosidase stability under sonication. Process Biochemistry, 41, 1493-1500.

SHAH, S. \& GUPTA, M. N. 2008. The effect of ultrasonic pretreatment on the catalytic activity of lipases in aqueous and non-aqueous media Chemistry Central Journal, 2, doi:10.1186/1752-153X-2-1.

SHAOBIN, G., WU, Y., LI, K., LI, S., MA, S., WANG, Q. \& WANG, R. 2010. A pilot study of the effect of audible sound on the growth of Escherichia coli. Colloids and Surfaces B:

Biointerfaces, 78, 367-371.

SHOW, K. Y., MAO, T. \& LEE, D. J. 2007. Optimisation of sludge disruption by sonication. Water Research, 41, 4741-4747.

SINESTERRA, J. V. 1992. Application of ultrasound to biotechnology: an overview. Ultrasonics, 30, 180-185.

TALUKDER, M. M. R., ZAMAN, M. M., WU, J. C. \& KAWANISHI, T. 2006. Ultrasonication enhanced hydrolytic activity of lipase in water/iso-octane two-phase systems. Biocataysis and Biotransformation, 24, 189-194.

TIAN, Z. M., WAN, M. X., WANG, S. P. \& KANG, J. Q. 2005. Effects of ultrasound and additives on the function and structure of trypsin Ultrasonics Sonochemistry, 11, 399-404.

TIEHM, A., NICKEL, K. \& NEIS, U. 1997. The use of ultrasound to accelerate the anaerobic digestion of sewage sludge. Water Science Technology, 36, 121-128. 
TIEHM, A., NICKEL, K., ZELLHORN, M. \& NEIS, U. 2001. Ultrasonic waste activated sludge disintegration for improving anaerobic stabilization. Water Research, 35, 2003-2009.

TOBA, T., HAYASAKA, I., TAGUCHI, S. \& ADACHI, S. 1990. A New Method for Manufacture of Lactose-Hydrolyzed Fermented Milk. Journal of the Science of Food and Agriculture, 52, 403407.

TOERIEN, D. F. \& HATTINGH, W. H. J. 1969. Review Paper. Anaerobic digestion. Part I. The microbiology of anaerobic digestion. . Water Research, 3:, 385-416.

VULFSON, E. N., SARNEY, D. B. \& LAW, B. A. 1991. Enhancement of subtilisin-catalyzed interesterification in organic-solvents by ultrasound irradiation. Enzyme and Microbial Technology, 13, 123-126.

WANG, D. \& SAKAKIBARA, M. 1997. Lactose hydrolysis and betagalactosidase activity in sonicated fermentation with Lactobacillus strains. Ultrasonics Sonochemistry, 4, 255-261.

WANG, D. Z., SAKAKIBARA, M., KONDOH, N. \& SUZUKI, K. 1996. Ultrasound-enhanced lactose hydrolysis in milk fermentation with Lactobacillus bulgaricus. Journal of Chemical Technology and Biotechnology, 65, 86-92.

WANG, F., LU, S. \& JI, M. 2006. Components of released liquid from ultrasonic waste activated sludge disintegration. Ultrasonics Sonochemistry, 13, 334-338.

WANG, J.-X., HUANG, Q.-D., HUANG, F.-H., WANG, J.-W. \& HUANG, Q.-J. 2007. Lipase-catalysed production of biodiesel from high acid value waste oil using utlrasonic assistant. Chinese Journal of Biotechnology, 23, 1211-1128.

WANG, J., CAO, Y., SUN, B., WANG, C. \& MO, Y. 2010a. Effect of ultrasound on the activity of allinase from fresh garlic. Ultrasonics Sonochemistry.

WANG, Z., WANG, R., TIAN, J., ZHAO, B., WEI, X. F., SU, Y. L., LI, C. Y., CAO, S. G., JI, T. F. \& WANG, L. 2010b. The effect of ultrasound on lipase-catalyzed regioselective acylation of mangiferin in non-aqueous solvents. Journal of Asian Natural Products Research, 12, 56-63.

WOOD, B. E., ALDRICH, H. C. \& INGRAM, L. O. 1997. Ultrasound stimlates ethanol production during the simultaneous saccharification and fermentation of mixed waste office paper. Biotechnol. Prog., 13, 1997.

WOOD, R. W. \& LOOMIS, A. L. 1927. The physical and biological effects of high frequency ultrasound-waves of great intensity. Phil. Mag., 4, 417-436.

XIAO, Y. M., WU, Q., CAI, Y. \& LIN, X. F. 2005. Ultrasoundaccelerated enzymatic synthesis of sugar esters in nonaqueous solvents. Carbohydrate Research, 340, 20972103. 
XIAO, Y. M., YANG, L. R., MAO, P., ZHAO, Z. \& LIN, X. F. 2011. Ultrasound-promoted enzymatic synthesis of troxerutin esters in nonaqueous solvents. Ultrasonics Sonochemistry, 18, 303309.

XIE, B., LIU, H. \& YAN, Y. 2009. Improvement of the activity of anaerobic sludge by low-intensity ultrasound. Journal of Environmental Management, 90, 260-264.

YACHMENEV, V., CONDON, B., KLASSON, T. \& LAMBERT, A. 2009. Acceleration of the Enzymatic Hydrolysis of Corn Stover and Sugar Cane Bagasse Celluloses by Low Intensity Uniform Ultrasound. Journal of Biobased Materials and Bioenergy, 3, 25-31.

YACHMENEV, V. G., BERTONIERE, N. R. \& BLANCHARD, E. J. 2001. Effect of sonication on cotton preparation with alkaline processes. Textile Research Journal, 71, 52-533.

YACHMENEV, V. G., BERTONIERE, N. R. \& BLANCHARD, E. J. 2002. Intensification of the bio-processing of cotton textiles by combined enzyme/ultrasound treatment. J. Chem. Technol. Biotechnol., 77, 559-567.

YACHMENEV, V. G., BLANCHARD, E. J. \& LAMBERT, A. H. 2004. Use of ultrasonic energy for intensification of the bio-preparation of greige cotton. Ultrasonics, 42, 87-91.

YANG, S. L., ZHANG, H., LI, Y. R., QIAN, J. \& WANG, W. 2005. The ultrasonic effect on biological characteristics of Monascus sp. Enzyme and Microbial Technology, 37, 139-144.

YANG, S. L., ZHANG, H. \& WANG, W. 2010. The ultrasonic effect on the mechanism of cholesterol oxidase production by Brevibacterium sp. African Journal of Biotechnology, 9, 25742578.

YASUDA, K., KATO, D., XU, Z., SAKKA, M. \& SAKKA, K. 2010. Effect of Ultrasonic Frequency on Enzymatic Hydrolysis of Cellulose. Japanese Journal of Applied Physics, 49, 07HE08.

YU, G. H., HE, P. J., SHAO, L. M. \& ZHU, Y. S. 2008. Extracellular proteins, polysaccharides and enzymes impact on sludge aerobic digestion after ultrasonic pretreatment. Water Research, 42, 1925-1934.

YU, G. H., HE, P. J., SHAO, L. M. \& ZHU, Y. S. 2009. Enzyme extraction by ultrasound from sludge flocs. Journal of Environmental Sciences, 21, 204-210.

ZABANEH, M. \& BAR, R. 1991. Ultrasound-enhanced bioprocess. 2. Dehydrogenation of hydrocortisone by arthrobacter-simplex Biotechnology and Bioengineering, 37, 998-1003.

ZHANG, G., ZHANG, P., GAO, J. \& CHEN, Y. 2008. Using acoustic cavitation to improve the bio-activity of activated sludge. Bioresource Technology, 99, 1497-1502. 